\title{
An Ag based brazing system with a tunable thermal expansion for the use as sealant for solid oxide cells
}

Ragnar Kiebach $^{* a}$, Kurt Engelbrecht ${ }^{a}$, Laila Grahl-Madsen ${ }^{b}$, Bertil Sieborg ${ }^{b}$, Ming Chen ${ }^{a}$, Johan Hjelm $^{a}$, Kion Norrman ${ }^{a}$, Christodoulos Chatzichristodoulou ${ }^{a}$ and Peter Vang Hendriksen ${ }^{a}$

${ }^{a}$ Department of Energy Conversion and Storage, Technical University of Denmark, Ris $\varnothing$ Campus, Frederiksborgvej 399, DK-4000 Roskilde, Denmark

${ }^{b}$ IRD Fuel Cell A/S, Kullinggade 31, DK-5700 Svenborg, Denmark

*Corresponding author: Tel.: +45 46775624. Fax: +45 46775688. Email address: woki@dtu.dk.

Keywords:

Brazing, Sealant, Solid Oxide Fuel Cell, Solid Oxide Electrolysis Cell, Silver, Corrosion

Abstract:

An $\mathrm{Ag}_{-} \mathrm{Al}_{2} \mathrm{TiO}_{5}$ composite braze was developed and successfully tested as seal for solid oxide cells. The thermo-mechanical properties of the $\mathrm{Ag}-\mathrm{Al}_{2} \mathrm{TiO}_{5}$ system and the chemical compatibility between this composite braze and relevant materials used in stacks were characterized and the leak rates as a function of the operation temperature were measured. 
The thermal expansion coefficient in the $\mathrm{Ag}-\mathrm{Al}_{2} \mathrm{TiO}_{5}$ system can be tailored by varying the amount of the ceramic filler. The brazing process can be carried out in air, the joining partners showed a good chemical stability and sufficient low leak rates were demonstrated. Furthermore, the long-term stability of the $\mathrm{Ag}-\mathrm{Al}_{2} \mathrm{TiO}_{5}$ composite braze was studied under relevant SOFC and SOEC conditions. The stability of brazed Crofer/ $\mathrm{Ag}-\mathrm{Al}_{2} \mathrm{TiO}_{5} / \mathrm{NiO}-\mathrm{YSZ}$ assemblies in reducing atmosphere and in pure oxygen was investigated over $500 \mathrm{~h}$ at $850{ }^{\circ} \mathrm{C}$. Additionally, a cell component test was performed to investigate the durability of the $\mathrm{Ag}$ $\mathrm{Al}_{2} \mathrm{TiO}_{5}$ seal when exposed to dual atmosphere. The seals performed well over $900 \mathrm{~h}$ under electrolysis operation conditions $\left(-0.5 \mathrm{~A} \mathrm{~cm}^{2}, 850^{\circ} \mathrm{C}\right)$, and no cell degradation related to the $\mathrm{Ag}$ $\mathrm{Al}_{2} \mathrm{TiO}_{5}$ sealing was found, indicating that the developed braze system is applicable for the use in SOFC/SOEC stacks.

\section{Introduction}

Research on solid oxide fuel cells (SOFC) as well as on hydrogen/syngas production using solid oxide electrolysis cells (SOEC) has increased in the last years [1-6]. The development and testing of sealing materials is a concern for stack developers, and several concepts using different materials are currently tested for gas seal applications. Glass and glass-ceramics have been the object of several studies in the last years [7-12], but problems like low thermal expansion coefficients (TEC) compared to other stack components [13-15] and the tendency to react with materials, have not yet been solved completely. Also crystallization during operation leads to changes in microstructure and mechanical properties, which may result in cracking and loss of 
gas tightness over time [16-18]. Seals in SOFC/SOEC stacks must also be tolerant to a high steam content and should have a low tendency to emit Si to avoid Si poising of the electrodes $[19,20]$. Especially the last point challenges the use of glass or glass ceramic seals.

Therefore, a number of alternative sealing techniques like compressive mica seals $[15,21,22]$ or brazing are under consideration. Especially brazing is particularly attractive for stack concepts requiring strong interfaces and good sealing also in the absence of a loading force on the seal. In this method a matrix material, with a melting point significantly below that of the materials to be joined, is heated until it melts or becomes sufficiently soft to fill out the gaps between the components to be joined.

Active metal brazing $(A M B)$ and reactive air brazing $(R A B)[15,17,23,24,26-38]$ are the two most studied brazing techniques for SOC (solid oxide cell) applications. In AMB, the used matrix contains an active metal addition like $\mathrm{Ti}$, $\mathrm{Zr}$ or $\mathrm{Hf}$, which reacts with the ceramic, e.g. YSZ (yttria stabilized zirconia, forming a layer at the interface, which lowers the interfacial energy and promotes wetting $[28,29,39]$. The disadvantage of $A M B$ is, that an inert atmosphere (Ar, He), a relatively strong vacuum $\left(<10^{-5} \mathrm{mbar}\right.$ ) or a reducing atmosphere is required during the sealing process to avoid an uncontrolled oxidation of the sealing material. Compared to simple air fired processes this entails a higher production cost. Also the low $\mathrm{pO}_{2}$ required during the brazing process could be problematic for the oxide materials used as SOC oxygen electrodes, if it lies below the decomposition $\mathrm{pO}_{2}$ of the applied compounds possibly leading to an irreversible deterioration due to phase separation. 
RAB brazes consist of a noble metal $(\mathrm{Ag}, \mathrm{Pd}, \mathrm{Au}, \mathrm{Pt})$ as matrix and an oxide component (typically $\mathrm{CuO}$ ) that partially dissolves in the molten noble metal [31-34,36,40,41]. Like in AMB, the oxide compound modifies or reacts with the surface of the (ceramic) substrate, and the newly formed surface is wetted by the molten filler. RAB joining can be carried out in air.

A disadvantage of using an Ag-CuO braze is that often a relatively thick layer ( $>20 \mu \mathrm{m})$ of metal oxides is formed as reaction product during the brazing. Especially for ferritic steels used for SOC applications (e.g. Crofer $22 \mathrm{APU}$ ), a layer of $\mathrm{Cr} / \mathrm{Cu} / \mathrm{Mn} / \mathrm{Fe}$-oxides is found due to the reaction of the $\mathrm{CuO}$ and the steel surface during the brazing procedure $[17,29,32,42,43]$. This reaction zone has been observed to be the mechanically weakest part in the joint and is prone to mechanical failure $[34,44]$. Another disadvantage of the RAB brazes is their high thermal expansion coefficient (TEC) compared to the other materials used in SOFC/SOEC stacks. Standard RAB brazes (Ag with $4 \% \mathrm{CuO}$ ) have a TEC of $20 \cdot 10^{-6} \mathrm{~K}^{-1}$, while the ceramic cells and the typically used steels have TECs between $10 \cdot 10^{-6} \mathrm{~K}^{-1}$ and $13 \cdot 10^{-6} \mathrm{~K}^{-1}$ ). This difference in TEC is problematic for the mechanical integrity, as the stresses and stored elastic energy in the stack, which can drive crack propagation, are proportional to it.

To overcome the problems of a thermal coefficient mismatch and the formation of a fragile reaction layer, a composite braze sealant using $\mathrm{Ag}$ with $\mathrm{Al}_{2} \mathrm{TiO}_{5}$ as ceramic filler has been developed. $\mathrm{Al}_{2} \mathrm{TiO}_{5}$ was chosen because of its chemical stability and for its very low thermal expansion coefficient of $1-210^{-6} \mathrm{~K}^{-1}[45,46]$.

In the study presented here, the thermo-mechanical properties of the $\mathrm{Ag}^{-} \mathrm{Al}_{2} \mathrm{TiO}_{5}$ system and the chemical compatibility between this composite braze and relevant stack components (YSZ, 
$\mathrm{NiO}$ and Crofer $22 \mathrm{APU}$ steel) of the braze are discussed. Also, the leak rates through a seal made of this composite braze was measured as a function of the operation temperature. Additionally, the long-term stability of the braze under SOFC/SOEC relevant conditions, including thermal cycling in SOFC/SOEC relevant atmospheres and the use as sealant in cell tests is described.

\section{Experimental}

\subsection{Materials and sample preparation}

Samples for differential scanning colorimetry (DCS) and dilatometry measurements were prepared by mixing Ag powder ( $1 \mu \mathrm{m}$, Sigma-Aldrich) and $\mathrm{Al}_{2} \mathrm{TiO}_{5}$ powder (Sigma-Aldrich). The mixed powders were pressed ( $2 \mathrm{t}$, uniaxial pressing) into rods with a diameter of $7 \mathrm{~mm}$ and $\sim 1.5$ $\mathrm{cm}$ in length. Samples with $5 \mathrm{wt} . \%, 10 \mathrm{wt} . \%, 15 \mathrm{wt} . \%$ and $17.5 \mathrm{wt} . \%$ of $\mathrm{Al}_{2} \mathrm{TiO}_{5}$ were produced. To obtain fully dense samples, the rods were sintered for $5 \mathrm{~h}$ at $900{ }^{\circ} \mathrm{C}$ in air. For dilatometry and mechanical measurements, the ends of the rods were cut parallel using a diamond saw after sintering.

For the joining as well as for the leak experiments Ag paste (CERMET SILVER CONDUCTOR 9907) from ESL Electro-Science was screen printed on the Crofer 22 APU (Thyssen Krupp) steel. Different amounts of $\mathrm{Al}_{2} \mathrm{TiO}_{5}$ (Sigma-Aldrich) with a particle size $<22 \mu \mathrm{m}$ were added to the pure $\mathrm{Ag}$ paste. The maximum amount of $\mathrm{Al}_{2} \mathrm{TiO}_{5}$ added was 10 wt. \% (based on $\mathrm{Ag}$ solid load in the ink). The addition of higher amounts of ceramic filler into the commercial Ag ink was not 
feasible, since inks containing such high amounts of ceramic filler had a high viscosity and were no longer printable. To achieve screen-printable inks with a higher amount of $\mathrm{Al}_{2} \mathrm{TiO}_{5}$ powder, an in-house ink was made by mixing $80 \mathrm{wt}$. \% Ag powder ( $1 \mu \mathrm{m}$, Sigma-Aldrich) and $20 \mathrm{wt. \%}$ $\mathrm{Al}_{2} \mathrm{TiO}_{5}$ powder $(<22 \mu \mathrm{m}$, Sigma-Aldrich). The mixed powders were added to the remaining organic ink components (Downnol ${ }^{\mathrm{TM}}$ (Dow chemical company), BLS ${ }^{\mathrm{TM}}$ (Mayzo), Disperbyk ${ }^{\circledR} 180$ (Altana) and Santicizer ${ }^{\circledast} 261 \mathrm{~A}$ (Ferro)). These inks were used in the long-term experiments described in 2.6.

For joining experiments, the Ag paste with the filler were screen printed on steel sheets. To obtain different thicknesses of the $\mathrm{Ag}$ braze, 1 to 3 layers were printed. In this multilayer printing process, the printed assembly was dried after each printing step at $120{ }^{\circ} \mathrm{C}$ in a belt furnace in air. Typically, one screen printed layer of $\mathrm{Ag}$ paste resulted in a $29 \mu \mathrm{m}$ thick joint after brazing. Planar NiO-YSZ-supported solid oxide cells half cells [47] were used as "joining partners" to the Crofer sheets. The cells have 10-13 $\mu \mathrm{m}$ thick dense YSZ electrolytes and are supported by $300 \mu \mathrm{m}$ thick NiO-YSZ layers. All materials were cut into $2 \mathrm{~cm} \times 2 \mathrm{~cm}$ specimens and the joining was conducted by placing the Crofer plates with the screen printed braze on top the dense YSZ electrolyte or the Ni-YSZ support of the non-reduced half-cells. To ensure contact during brazing a load of $3.2 \mathrm{~kg} / \mathrm{cm}^{2}$ was applied. The assemblies were heated in air with $100 \mathrm{~K} / \mathrm{h}$ to the final brazing temperature, which varied between $920^{\circ} \mathrm{C}$ and $950{ }^{\circ} \mathrm{C}$. After $20 \mathrm{~min}$ at the brazing temperature the samples were cooled down $\left(60^{\circ} \mathrm{C} / \mathrm{h}\right)$ to room temperature.

\subsection{Differential scanning colorimeter and dilatometry}


The melting points of the composite brazes were measured using a Differential Scanning Calorimeter (DSC) Netzsch DSC 404 C. Measurements were performed in argon with a heating rate of $10{ }^{\circ} \mathrm{C} / \mathrm{min}$ up to $1350{ }^{\circ} \mathrm{C}$. Specimens with parallel ends were used for the dilatometry, which was carried out in $\mathrm{N}_{2}$-atmosphere in a Netzsch DIL 404C applying a heating rate of $3^{\circ} \mathrm{C} / \mathrm{min}$ to $800^{\circ} \mathrm{C}$ and using the automatic "softening point detection" (provided in the Netzsch Software) to be sure that the sample did not melt during the measurement.

\subsection{SEM/EDX}

Brazed assemblies were prepared for SEM analysis by vacuum embedding in Struers epoxy resin $\left(\right.$ Epofix $\left.^{\circledR}\right)$. The samples were cut along the center of the assembly, and the cross sections were ground using SiC paper and polished using $6 \mu \mathrm{m}, 3 \mu \mathrm{m}$ and $1 \mu \mathrm{m}$ diamond paste. Micrographs and EDX spectra were recorded on a Zeiss Supra 35 scanning electron microscope (SEM) equipped with a field emission gun and an EDX detector or on a TM3000 (Hitachi) table top microscope .

\subsection{Leak testing}

For leak testing, gaskets were made from square Crofer steel frames (53×53mm) with a breadth of $5 \mathrm{~mm}$ used as sealing area. Three Layers of $\mathrm{Ag}$ or $\mathrm{Ag}-\mathrm{Al}_{2} \mathrm{TiO}_{5}$ braze were screen printed on each side of the steel frame as seal. The gaskets were tested at IRD Fuel Cell A/S in an in-house made alumina test house. Detailed information about the experimental setup and data treatment can be found in the supplementary material.

2.6 Long-term testing in reducing and oxidizing atmospheres 
Four different sets of experiments were performed to investigate the capability to withstand thermal cycling and the long-term stability of the brazing material. The samples were placed inside an alumina crucible and annealed in a horizontal tube furnace. The annealing temperature was $850^{\circ} \mathrm{C}$ with heating rates and cooling rates of $100 \mathrm{~K} / \mathrm{h}$. Hydrogen was diluted by inert gas to keep a safe concentration range. The gas flow rate was kept constant at $6 \mathrm{l} / \mathrm{h}$ during the experiments. The steam was supplied by a water container kept at a specific temperature $\left(80^{\circ} \mathrm{C}\right.$ for $50 \%$ humidity) and constantly purged with gas. In each case 6 assemblies were annealed in wet reducing atmosphere $\left(4.5 \% \mathrm{H}_{2}, 50 \% \mathrm{H}_{2} \mathrm{O}, 45.5 \% \mathrm{Ar}\right)$ and 6 in pure oxygen for $500 \mathrm{~h}$. After this period, 3 samples of each set were removed (samples without thermal cycling) and the remaining 3 samples were exposed to 8 thermal cycles using the following temperature profile: Heating with $100 \mathrm{~K} / \mathrm{h}$ to $850^{\circ} \mathrm{C}$, hold for $24 \mathrm{~h}$, cooling down to 30 ${ }^{\circ} \mathrm{C}$ with $100 \mathrm{~K} / \mathrm{h}$. The chosen number of cycles is based on in-house experiments with other sealing materials. Typically for materials which cannot withstand thermal cycling, after 8 cycles clear indications for degradation can be observed.

\subsection{Component testing}

To study the influence of different SOC auxiliary components like interconnects or sealants on the cell performance under realistic test conditions a component test setup developed at DTU was used. A detailed description and drawings of the setup can be found in the supplementary material.

2.5 Secondary Ion Mass Spectroscopy (TOF-SIMS) 
TOF-SIMS analyses were performed using a TOF-SIMS IV (ION-TOF GmbH, Münster, Germany). In order to optimize the imaging quality the surface was in each case sputter cleaned in order to remove physisorped hydrocarbons and possible smeared epoxy. TOF-SIMS analyses was performed in a high resolution mode corresponding to low and high image resolution. The following primary ion conditions were used: $25-\mathrm{ns}$ pulses of $25-\mathrm{keV} \mathrm{Bi}^{+}$, which were bunched to form ion packets with a nominal temporal extent of $<1 \mathrm{~ns}$ at a repetition rate of $10 \mathrm{kHz}$ yielding a target current of $1 \mathrm{pA}$. An electron gun was used to minimize charging of the surface. Desorbed secondary ions were accelerated to $2 \mathrm{keV}$, mass analyzed in the flight tube, and postaccelerated to $10 \mathrm{keV}$ before detection. The TOF-SIMS IV software package (version 4.0) was employed to process the data. The mass spectral data was mass calibrated using lonSpec section of TOF-SIMS IV. The identity of a given signal was determined from the exact mass combined with isotope pattern recognition. The signal intensities were acquired from peak areas by integrating the mass spectral peaks. Intensities were visualized in 256 pixel $\times 256$ pixel images using the lonImage section of TOF-SIMS IV.

3 Results and Discussion

\subsection{Thermo-mechanical properties}

Typically, SOC components have matching TECs between $10.5-12 \cdot 10^{-6} \mathrm{~K}^{-1}$ (Crofer APU 22 12.3 $10^{-6} \mathrm{~K}^{-1}, \mathrm{YSZ} 10.8 \cdot 10^{-6} \mathrm{~K}^{-1}, \mathrm{Ni}-\mathrm{YSZ} 12.6 \cdot 10^{-6} \mathrm{~K}^{-1}$ ) to reduce thermal stresses and minimize the risk of cracking/mechanical failure during operation. The TEC of pure Ag is around $21 \cdot 10^{-6} \mathrm{~K}^{-1}$ (Fig. 1), which is much higher than the ones of typical SOC materials discussed above. To create 
a better TEC match, addition of particulate ceramic fillers to brazes to lower the TEC has been used $[38,41]$. Mainly $\mathrm{Al}_{2} \mathrm{O}_{3}$ was used, but $\mathrm{Al}_{2} \mathrm{TiO}_{5}$ has been applied as particulate filler in TiCuSil brazes [38]. In these composite brazes, a better TEC match can be created by a) increasing the amount of filler material or b) by using filler particles, which have a very low TEC. On this basis, $\mathrm{Al}_{2} \mathrm{TiO}_{5}$ with a TEC of $1 \cdot 10^{-6} \mathrm{~K}^{-1}$ is a better candidate than $\mathrm{Al}_{2} \mathrm{O}_{3}\left(\mathrm{TEC} 7 \cdot 10^{-6} \mathrm{~K}^{-1}\right)$ to reduce the overall TEC of an alloy-ceramic composite braze material.

Here, the influence of different amounts of $\mathrm{Al}_{2} \mathrm{TiO}_{5}$ on the thermo-mechanical properties of an Ag- $\mathrm{Al}_{2} \mathrm{TiO}_{5}$ composite braze was studied using dilatometry and differential scanning calorimetry.

\subsubsection{Dilatometry}

Figure 1a shows the TEC curves of pure silver and the composite brazes with 5 and 15 wt.\% of ceramic filler. The TEC was obtained from the slope of the strain over temperature plots, the region between $200{ }^{\circ} \mathrm{C}$ and $800{ }^{\circ} \mathrm{C}$ was used for evaluation. In this temperature range important for SOC operation, no sudden changes/jumps in the TEC of the Ag based brazes were found.

The TECs of various braze mixtures with different $\mathrm{Al}_{2} \mathrm{TiO}_{5}$ loading are plotted in Figure $1 \mathrm{~b}$. It was found that the TEC reduced obviously when $\mathrm{Al}_{2} \mathrm{TiO}_{5}$ was added to the $\mathrm{Ag}$. In general, the TEC decreases linear with the amount of ceramic filler. As indicated, an amount of $20 \mathrm{wt} \%$ of $\mathrm{Al}_{2} \mathrm{TiO}_{5}$ would result in a composite braze with a TEC of $12 \cdot 10^{-6} \mathrm{~K}^{-1}$, comparable to typical interconnect steels/ cell parts, and TEC can be tuned within the desired range. 


\subsubsection{Differential scanning colorimetry (DCS)}

To investigate the thermal stability and a possible reaction between the $\mathrm{Ag}$ and the ceramic filler, different compositions ranging from pure $\mathrm{Ag}$ up to 17 wt. \% of $\mathrm{Al}_{2} \mathrm{TiO}_{5}$ were analyzed using differential scanning calorimetry. In all cases, an endothermic event occurred at $962{ }^{\circ} \mathrm{C}$, which is the melting of $\mathrm{Ag}$. The melting point and behavior of the $\mathrm{Ag}$ is not influenced by the presence of the ceramic filler. The absence of any other events shows that there are no reaction between the $\mathrm{Al}_{2} \mathrm{TiO}_{5}$ filler and the $\mathrm{Ag}$. $\mathrm{Al}_{2} \mathrm{TiO}_{5}$ is stable up to $1300{ }^{\circ} \mathrm{C}$, making it an applicable, chemically inert filler material for the composite braze system. Further details of DCS measurements can be found in the supplementary material.

\subsection{Joining of SOFC/SOEC components}

\subsubsection{Influence of brazing parameters}

Pure $\mathrm{Ag}$ braze and with addition of 10 wt. $\% \mathrm{Al}_{2} \mathrm{TiO}_{5}$ were used to join Crofer APU 22 to a) a dense YSZ electrolyte $(\sim 10 \mu \mathrm{m})$ and b) to the porous NiO-YSZ anode supports. These types of assemblies were investigated as they reflect relevant joints in SOFC stacks.

Overview cross section images of the resulting joints brazed at different temperatures under a constant weight load of $3.2 \mathrm{~kg} / \mathrm{cm}^{2}$ are shown in Figure 2 . All samples shown in the images displayed good/sufficient bonding to the Crofer steel and the NiO-YSZ support of the SOC halfcell. These examples illustrate that the $\mathrm{Ag}-\mathrm{Al}_{2} \mathrm{TiO}_{5}$ composite can be brazed in a temperature

range from $920^{\circ} \mathrm{C}$ to $950{ }^{\circ} \mathrm{C}$. The best joints were obtained at a brazing temperature around $935^{\circ} \mathrm{C}$ (Fig. 2b). In this case a good adhesion towards the NiO-YSZ and the Crofer is found and 
the $\mathrm{Al}_{2} \mathrm{TiO}_{5}$ particles (grey inclusions in the $\mathrm{Ag}$ braze) are evenly distributed. Only a few voids are formed during the brazing process (black-dark grey inclusions in the Ag braze). When the assembly is joined at lower temperatures, the number of voids in the braze is higher, as clearly visible in the sample joint at $920{ }^{\circ} \mathrm{C}$ with a pure $\mathrm{Ag}$ braze (Fig. 2a). At higher sealing temperatures around $950{ }^{\circ} \mathrm{C}$ the $\mathrm{Ag}$ starts to diffuse into the porous NiO-YSZ substrate (arrows in Fig. 2c). The pressure/weight load applied during the sealing process influences the suitable temperature window for the brazing. A higher pressure at the same temperature will on one hand reduces the number of voids, but at the same time facilitate the diffusion of $\mathrm{Ag}$ into porous structures. Therefore, the optimal joining temperature for a given load should be determined for each desired assembly. Here, the pressure was kept constant at $3.2 \mathrm{~kg} / \mathrm{cm}^{2}$ and a brazing temperature of $930{ }^{\circ} \mathrm{C}$ was used. Interestingly this temperature is more than $30{ }^{\circ} \mathrm{C}$ below the actual melting point of $\mathrm{Ag}$, indicating that at this load the braze is already soft enough for ensuring the needed material distribution.

\subsubsection{Joining with $\mathrm{Ag}^{-} \mathrm{Al}_{2} \mathrm{TiO}_{5}$ braze}

In the following sections, joining experiments with the $\mathrm{Ag}^{-} \mathrm{Al}_{2} \mathrm{TiO}_{5}$ composite braze are described. Similar experiments have been made with pure Ag for comparison. The results of the experiments with pure $\mathrm{Ag}$ are described in detail in the supplementary material for the interested reader.

\subsubsection{Crofer/ $\mathrm{Ag}-\mathrm{Al}_{2} \mathrm{TiO}_{5} / \mathrm{NiO}-\mathrm{YSZ}$}

An overview SEM image of the NiO-YSZ substrate brazed to Crofer using the $\mathrm{Ag}^{-\mathrm{Al}_{2} \mathrm{TiO}_{5}}$ composite is shown in Figure 3a. The braze wets the NiO-YSZ and the Crofer steel well, 
producing a high quality joint. The thickness of the $\mathrm{Ag}^{-} \mathrm{Al}_{2} \mathrm{TiO}_{5}$ braze layer is around $70 \mu \mathrm{m}$ and few air pockets/voids are found (Fig. 3a). The ceramic $\mathrm{Al}_{2} \mathrm{TiO}_{5}$ particles with sizes ranging from 3-22 $\mu \mathrm{m}$ are evenly distributed in the Ag braze (Fig 3a). In some places small gaps/voids can be found around the ceramic particles. An EDS analysis (Table 1) (pt 2 Fig. 3b, pt4 Fig. 3c) confirmed the expected composition of the $\mathrm{Al}_{2} \mathrm{TiO}_{5}$ particles, no phase separation is found within in the particles, which is in agreement with the results from thermal analysis. As visible in Figure $3 \mathrm{c}$ and $3 \mathrm{~d}$, no reaction between the $\mathrm{Al}_{2} \mathrm{TiO}_{5}$ particles and the $\mathrm{Ag}$ is found. The reaction and inter-diffusion at the interface towards NiO-YSZ and Crofer are comparable with the ones for the pure Ag braze. No Ni diffusion into the Ag is found, in a few places the Ag diffuses into the pores of the NiO-YSZ substrate, but no reaction between the substrate and the braze is observed (pt 3-5, Fig. 3b). The Crofer steel is protected by a $(\mathrm{Mn}, \mathrm{Cr})_{3} \mathrm{O}_{4}$ oxide layer (pt 1-3, Fig. 3c) and $\mathrm{FeO}$ and $\mathrm{Cr}_{2} \mathrm{O}_{3}$ inclusion were found throughout the $\mathrm{Ag}$ braze, even close to $\mathrm{NiO}-\mathrm{YSZ}$ substrate (pt 3, Fig. $3 \mathrm{~b}$ ), and around the $\mathrm{Al}_{2} \mathrm{TiO}_{5}$ particles, indicating a high mobility of $\mathrm{Fe}$ and $\mathrm{Cr}$ during the brazing process.

\subsubsection{Crofer/ $\mathrm{Ag}-\mathrm{Al}_{2} \mathrm{TiO}_{5} / \mathrm{YSZ}$}

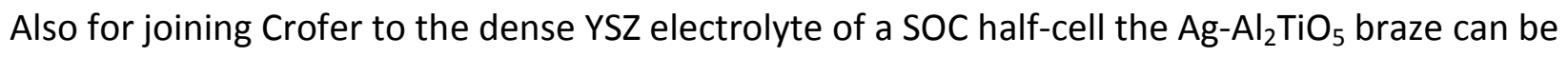
used as shown in Figure 3f. No differences in the $\mathrm{Al}_{2} \mathrm{TiO}_{5}$ particle distribution or the layer thickness compared to the assembly described above were found, and results from EDS analysis

(Fig. 3i,j) of the filler particles are comparable (pt 3, Fig. 3g and pt 4 Fig. 3h). The formation of voids in the bulk $\mathrm{Ag}$ and in some places around the $\mathrm{Al}_{2} \mathrm{TiO}_{5}$ particles is observed here as well. As expected, no reaction between the dense YSZ and the Ag was found, the YSZ surface is evenly 
wetted (Fig. 3h,j). Also in this sample an oxide layer consisting of chromium oxide $\left(\mathrm{Cr}_{2} \mathrm{O}_{3}\right)$ and chromium manganese spinel $(\mathrm{Mn}, \mathrm{Cr})_{3} \mathrm{O}_{4}$ with a thickness varying from 2-4 $\mu \mathrm{m}$ is found on the Crofer steel (pt4-6, Fig. 3i).

\subsection{Leak rate}

The air permeabilities of the Crofer gaskets with pure $\mathrm{Ag}$ braze or $\mathrm{Ag}-\mathrm{Al}_{2} \mathrm{TiO}_{5}$ composite braze were measured in a temperature range from $650{ }^{\circ} \mathrm{C}$ to $850{ }^{\circ} \mathrm{C}$ and from $600{ }^{\circ} \mathrm{C}$ to $800{ }^{\circ} \mathrm{C}$, respectively. The measured air permeabilities were converted into equivalent hydrogen leak rates (for details see supplementary information). Both gaskets possesses good gas tightness, the values are comparable to the ones reported in literature for $\mathrm{Ag} / \mathrm{Ag}-\mathrm{Al}{ }_{2} \mathrm{O}_{3}$ brazes [41]. It is concluded that Crofer steel frames with either pure $\mathrm{Ag}$ or $\mathrm{Ag}_{-} \mathrm{Al}_{2} \mathrm{TiO}_{5}$ composite braze possesses sufficient sealant properties, when a sealing temperature of $940{ }^{\circ} \mathrm{C}$ and sufficient pressure is applied. The leak rates for pure $\mathrm{Ag}(0.02$ to $0.225 \mathrm{sccm})$ are lower than the ones obtained for $\mathrm{Ag}_{-} \mathrm{Al}_{2} \mathrm{TiO}_{5}(0.2$ to $0.9 \mathrm{sccm})$. A similar trend with an increasing leak rate with increasing filler amount was reported by Zhou et al. [41]. For both brazes, a trend for higher leak rates at high temperatures is found. This tendency is more pronounced for the pure Ag braze. Low fuel leak rates are required if SOFC stacks are to operate safely and economically. Although, the allowable leak rates will be design and application specific, common sense points to the use of sealing materials offering leak rates as low as possible. Considering the leak rates reported here, for a 10-cell $\left(10 \mathrm{~cm} \times 10 \mathrm{~cm}\right.$ active area per cell) stack, operating at $0.5 \mathrm{~A} / \mathrm{cm}^{2}$ on hydrogen at $50 \%$ fuel utilization, $20 \%$ oxygen utilization at $750{ }^{\circ} \mathrm{C}$, the total gas rate entering the anode is estimated to be $7000 \mathrm{sccm}$. Assuming a leak rate of $0.2 \mathrm{sccm}$ (per $\mathrm{cm}$ of seal 
length) measured in this study applied to full-size stacks, the total parasitic hydrogen lost for the stack would be $1.25 \%$ of the total fuel rate at $20 \mathrm{kPa}$ pressure gradient across the seal (a seal length of $440 \mathrm{~cm}$ was assumed). Such values are expectable for several applications. It can be assumed that the leak rate in a real stack will be even lower, because the thermal mismatch between ferritic steel and the $\mathrm{Ag}$ will be significantly lower than the one between $\mathrm{Ag}$ and alumina in the here used test-setup.

\subsection{Stability in reducing atmosphere}

A SEM image of a cross section of a brazed Crofer/Ag- $\mathrm{Al}_{2} \mathrm{TiO}_{5} / \mathrm{Ni}-\mathrm{YSZ}$ assembly after ageing for $500 \mathrm{~h}$ in reducing atmosphere $\left(4.5 \% \mathrm{H}_{2}, 50 \% \mathrm{H}_{2} \mathrm{O}, 45.5 \% \mathrm{Ar}\right)$ is shown in Figure $4 \mathrm{a}$. The $\mathrm{Ag}$ based braze still wets the Crofer steel and the Ni-YSZ surface sufficiently. No indications of spalling were found, and no reactions between the $\mathrm{Al}_{2} \mathrm{TiO}_{5}$ particles and other components (e.g. $\mathrm{Ag}$, Crofer steel or $\mathrm{Ni}-\mathrm{YSZ}$ ) were observed. Only a partial decomposition of the $\mathrm{Al}_{2} \mathrm{TiO}_{5}$ particles to $\mathrm{Al}_{2} \mathrm{O}_{3}$ and $\mathrm{TiO}_{2}$ can be assumed on the basis of the EDS analysis (Table 2) (pt 6, Fig. 4a) and the difference in contrast within the particles observable in SEM image (Fig. 4a). Cracks or porosity related to the formation gaseous $\mathrm{H}_{2} \mathrm{O}$ bubbles in the braze was not observed. Interestingly, a dense oxide scale consisting of chromium oxide $\left(\mathrm{Cr}_{2} \mathrm{O}_{3}\right)$ and chromium manganese spinel $(\mathrm{Mn}, \mathrm{Cr})_{3} \mathrm{O}_{4}$, which is typically found on oxidized Crofer after the air brazing process, was not observed. Only small amounts of $\mathrm{Cr}_{2} \mathrm{O}_{3}$ in form of a non-continuous layer between the steel and the braze are visible (pt 3+5, Fig. 4a). On the other hand, Ag seems to form enclosures within the Crofer steel (pt 4, Fig. 4a). While a $(\mathrm{Mn}, \mathrm{Cr})_{3} \mathrm{O}_{4}$ scale was absent between the steel and the braze, such an oxide scale with a thickness of several $\mu \mathrm{m}$ was found 
between the braze and the Ni-YSZ (pt 8+9, Fig. 4a). The formation of such a layer can be explained with the migration of $\mathrm{Cr}, \mathrm{Mn}$ and, to a small extent, Fe ions from the steel through the silver. The evolving space in the steel seems to be filled up with Ag. Also in the $\mathrm{Ag}$ small particles of $\mathrm{Cr}_{2} \mathrm{O}_{3}$ can be found. How such an inter-diffusion and the reduction of a protective corrosion scale on the Crofer steel will affect the functionality of the seal in the long term, and if it can be prevented by a coating is difficult to predict and needs further investigation. It should be mentioned that this phenomena were also observed in the cell component test, but had no negative influence on the long-term stability as discussed in detail in section 3.7.

\subsection{Stability in oxidizing atmosphere}

For investigation the long-term stability in highly oxidizing atmosphere, the Crofer/Ag- $\mathrm{Al}_{2} \mathrm{TiO}_{5} /$ YSZ/Ni-YSZ assemblies were aged for $500 \mathrm{~h}$ in pure oxygen at $850{ }^{\circ} \mathrm{C}$. In around $50 \%$ of the samples a delamination between the steel and the braze was observed. In the following section first the intact samples will be described, the degradation mechanisms leading to a delamination are discussed separately afterwards. An influence of thermal cycling on the stability of the microstructure in aged samples was not found, delamination occurred as often in thermally cycled as in non-cycled samples.

\subsubsection{Non-delaminated samples}

A SEM image of the cross section of the Crofer/Ag- $\mathrm{Al}_{2} \mathrm{TiO}_{5} / \mathrm{YSZ}$ sample annealed for $500 \mathrm{~h}$ in pure oxygen is shown in Figure 4b. The exposure to oxygen did not lead to any reactions 
between the $\mathrm{Al}_{2} \mathrm{TiO}_{5}$ particles the other components or joining partners (Table 2) (pt 4, Fig. 4b), the formation of cracks or voids was not observed. A dense oxide scale on top of the Crofer steel was found (pt 2, Fig. 4b). Compared to the as brazed sample, the thickness of the oxide scale increased from 2-3 $\mu \mathrm{m}$ to around 4-5 $\mu \mathrm{m}$. Only small amounts of $\mathrm{Cr}_{2} \mathrm{O}_{3}$ near the YSZ electrolyte were found (pt 5, Fig. 4b). Like in the samples aged in reducing atmosphere (section 3.4), Ag enclosures are observed between the oxide the scale and the (non-oxidized) metal. But compared to the sample exposed to reducing atmosphere, the Ag enclosures found here are lower in number and smaller. Also the oxide scale found here is continuous.

\subsubsection{Degradation I: Delamination}

As shown in Figure 4c, the Crofer steel delaminated in some cases from the $\mathrm{Ag}-\mathrm{Al}_{2} \mathrm{TiO}_{5}$ braze after $500 \mathrm{~h}$ of ageing in oxygen. The weak point in the joint is between the Crofer steel and the formed $(\mathrm{Mn}, \mathrm{Cr})_{3} \mathrm{O}_{4}$ scale. As observable in Figure $4 \mathrm{c}$, the oxide scale is still well attached to the Ag- $\mathrm{Al}_{2} \mathrm{TiO}_{5}$ braze. On the steel interface exposed to the oxygen after delamination only a small oxide scale is found. Therefore, the $\mathrm{Ag}-\mathrm{Al}_{2} \mathrm{TiO}_{5}$ braze cannot be considered the problematic component leading to the instability of the joint assembly. One should also take into consideration, that no weight load was applied on the samples during ageing. Since SOFC/SOEC stacks operate under pressure load, such an external pressure could stabilize the joint.

\subsubsection{Degradation II: Formation of Ag-Cr-oxides}

As a second degradation mechanism, $\mathrm{Cr}$ enrichment in the Ag braze near the oxidized Crofer steel was identified. As shown in Figure 4b, the braze close to the YSZ (pt 8, Fig. 4c) has a brighter contrast than the Ag braze close to the steel (pt 3,7+9, Fig. 4c, indicating a different 
elemental composition, which was confirmed by EDS analysis. Due to the homogenous contrast in the SEM image (Fig. 4c), it can be assumed that the newly formed $\mathrm{Cr}$ containing phase is consistent in its chemical composition. One possible phase could be $\mathrm{Ag}_{2} \mathrm{CrO}_{4}$, which can form during the cooling down process below $600{ }^{\circ} \mathrm{C}$ in high $\mathrm{pO}_{2}$. A distinct confirmation of this phase was not possible due to the possible presence of $\mathrm{Cr}_{2} \mathrm{O}_{3}$ and $\mathrm{Al}_{2} \mathrm{TiO}_{5}$ particles in the braze, which can cause an inaccuracy on the measured chromium and oxygen content, but the $\mathrm{Ag} / \mathrm{Cr}$ ratio of 2 in pt 7 and pt 9 is a strong indication for the presence of this phase.

\subsubsection{Degradation III: Evaporation of $\mathrm{Ag}$}

At the edges of the "sandwich" structures and in delaminated samples where a large area of the Ag-braze was exposed to the $\mathrm{O}_{2}$ atmosphere, an evaporation/redistribution of $\mathrm{Ag}$ was found (Fig. 4d). Interestingly, the Ag partly migrated to the other side of the Crofer steel piece

(Fig.4d, inlet). An explanation for this behavior cannot be given at this point. The evaporation of $\mathrm{Ag}$ should be independent from the atmosphere [48], since Ag evaporates in elemental from and not as oxides/hydroxide or hydride. A possible explanation could be that this degradation phenomenon is linked/enhanced with the formation of $\mathrm{Ag}_{2} \mathrm{CrO}_{4}$ [43] and facilitated by the increased area caused by delamination. This would be in agreement with results from Sofie et al. and Abernathy at al. $[42,43]$ who reported the presence of $\mathrm{AgCrO}_{2}$ and $\mathrm{Ag}_{2} \mathrm{CrO}_{4}$ in silver when exposed to chromium source.

$$
8 \mathrm{Ag}+\mathrm{Cr}_{2} \mathrm{O}_{3}+5 \mathrm{O}_{2}->4 \mathrm{Ag}_{2} \mathrm{CrO}_{4}(1)
$$

The problem with $\mathrm{Ag}_{2} \mathrm{CrO}_{4}$ is its low melting of $658{ }^{\circ} \mathrm{C}$, which is lower than that of silver (962 $\left.{ }^{\circ} \mathrm{C}\right)$, meaning that within the test conditions used here, $\mathrm{Ag}_{2} \mathrm{CrO}_{4}$ could melt and volatize. Such a 
continuous evaporation of the formed $\mathrm{Ag}_{2} \mathrm{CrO}_{4}$ could explain the formed microstructures in Figure 4d.

\subsection{Influence of thermal cycling /shock resistance}

After $500 \mathrm{~h}$ in $\mathrm{H}_{2} \mathrm{O} / \mathrm{H}_{2} / \mathrm{Ar}$ atmosphere, the brazed assemblies were exposed to 8 additional thermal cycles. Here, the samples were heated up to $850{ }^{\circ} \mathrm{C}$ with $100 \mathrm{~K} / \mathrm{h}$ and cooled down to $30{ }^{\circ} \mathrm{C}$ with $100 \mathrm{~K} / \mathrm{h}$. Excellent thermal cyclability and shock resistance were found, and no changes in the microstructure were observed. The interfaces Crofer steel/Ag- $\mathrm{Al}_{2} \mathrm{TiO}_{5}$ braze and Ag- $\mathrm{Al}_{2} \mathrm{TiO}_{5}$ braze/Ni-YSZ support are stable and all joining partners were still in good contact, no cracks or delamination were found. In all 6 samples only one spot with delamination was found. In this case, at the edge of the sample the $(\mathrm{Mn}, \mathrm{Cr})_{3} \mathrm{O}_{4}$ oxide scale was spalled off from the steel, the $(\mathrm{Mn}, \mathrm{Cr})_{3} \mathrm{O}_{4}$ oxide scale was still tightly joined to the $\mathrm{Ag}-\mathrm{Al}_{2} \mathrm{TiO}_{5}$ braze, indicating that the adherence of the braze is rather strong and the mechanical weak point in this sample is between the oxide scale and the steel. Also for samples oxidized in $\mathrm{O}_{2}$ for $500 \mathrm{~h}$ no changes after thermal cycling (identical to the temperature profile described above) in the microstructure compared to non-cycled samples were found. The degradation mechanism occurred to the same extent in both types of samples. In general it can be stated, that thermal cycling has no effect on the stability of the $\mathrm{Ag}-\mathrm{Al}_{2} \mathrm{TiO}_{5}$ braze, regardless the operation conditions the braze is exposed to.

3.7 Cell component test with $\mathrm{Ag}-\mathrm{Al}_{2} \mathrm{TiO}_{5}$ seal

3.7.1 Electrochemical testing 
To test the long term stability of the $\mathrm{Ag}-\mathrm{Al}_{2} \mathrm{TiO}_{5}$ braze, a cell component test (described in the supplementary material) was performed. The main focus of this test was to investigate the durability of the $\mathrm{Ag}-\mathrm{Al}_{2} \mathrm{TiO}_{5}$ seal over a longer period when exposed to dual atmosphere (air on one side and $\mathrm{H}_{2}$ on the other side of the seal). The test was carried under electrolysis operation conditions: $-0.5 \mathrm{~A} / \mathrm{cm}^{2}$ at $850{ }^{\circ} \mathrm{C}$, applying a mixture of $50 \%$ steam and $50 \%$ hydrogen to the $\mathrm{Ni}$ /YSZ electrode and pure oxygen to the LSM/YSZ electrode. A plot of the cell voltage during the electrolysis testing is shown in the supplementary material. The electrolysis study was carried out for $900 \mathrm{~h}$. After an initial degradation of $230 \mathrm{mV}$ in the first $200 \mathrm{~h}$ of the test, the cell showed a long term activation of $-94 \mathrm{mV} / 1000 \mathrm{~h}$ for the rest of the testing period. The open circuit voltage under the above described test conditions was $954 \mathrm{mV}$ before and $950 \mathrm{mV}$ after the testing period. For the hole testing period no indication for a degradation related to a leakage in the seal was found.

\subsubsection{SEM/EDX analysis of the $\mathrm{Ag}-\mathrm{Al}_{2} \mathrm{TiO}_{5}$ seal}

In Figure 5a an overview SEM image of the sealing area is shown. The composite braze is evenly distributed between the interconnect and the spacer as well as between spacer and the cell. The further analysis focuses on the following three location of the sealing area: a) the center of the sealing area marked as "bulk" in Figure $5 a, b)$ the inner rim of the seal exposed to the fuel gas $\left(\mathrm{H}_{2} / \mathrm{H}_{2} \mathrm{O}\right)$ (left in Fig. 5a) and c) the outer rim of the seal exposed to air (right in Fig. 5a).

\subsubsection{Center of the seal}

As shown in Figure 5b, the braze wets the steel surface sufficiently, the roughness and irregularities in thickness, caused by the manufacturing process of the interconnect, are 
completely covered and evened out by the $\mathrm{Ag}-\mathrm{Al}_{2} \mathrm{TiO}_{5}$ braze. The formation of water bubbles, caused by the exposure to dual atmosphere, which was reported as possible problem in literature [49], was not observed. Only small pores (Fig. 5b) appear sporadically around the $\mathrm{Al}_{2} \mathrm{TiO}_{5}$ particles, a phenomenon also found in as-brazed samples. The $\mathrm{Ag}-\mathrm{Al}_{2} \mathrm{TiO}_{5}$ braze does not show any deformation indicative of a mechanical failure after an operation time of $900 \mathrm{~h}$ at $850^{\circ} \mathrm{C}$. After the sealing process the braze and the Ni contact layer form a tight joint. The larger pores in the Ni layer are only partly penetrated with the Ag braze, but still the contact is good enough to provide a sufficiently gas tight seal. In some parts in the center of the sealing area, a delamination between the $\mathrm{Ni}$ layer and the Ni-YSZ support is observed (Fig. 5), indicating a mechanically strong bond between the $\mathrm{Ag}-\mathrm{Al}_{2} \mathrm{TiO}_{5}$ braze and the Ni layer. On the surface of the Crofer steel an oxide scale consisting of $(\mathrm{Mn}, \mathrm{Cr})_{3} \mathrm{O}_{4}, \mathrm{NiO}$ and traces of $\mathrm{FeO}_{x}$ is found, indicating a diffusion of the $\mathrm{Ni}$ from the cell through the braze to the steel. Also around the $\mathrm{Al}_{2} \mathrm{TiO}_{5}$ particles in some places an enrichment of $\mathrm{Cr}_{2} \mathrm{O}_{3}$ is found. These findings are comparable with results for the as-brazed samples described in the first part of this paper, indicating the main diffusion of these elements in the bulk of the sealing occurs during the brazing process and not under operation.

\subsubsection{Rim of the seal exposed to fuel gas}

A SEM image of the rim of the sealing area after exposure to the fuel gas $\left(50 \% \mathrm{H}_{2} / 50 \% \mathrm{H}_{2} \mathrm{O}\right)$ for $900 \mathrm{~h}$ is shown in Figure $6 \mathrm{a}$. In the areas were the $\mathrm{Ag}_{-} \mathrm{Al}_{2} \mathrm{TiO}_{5}$ braze was in direct contact with the fuel gas, an enrichment of metal oxides onto of the braze is found. As shown in the EDS maps in Figure $6 \mathrm{~b}$ and $\mathrm{c}$, this outer layer consists of a $(\mathrm{Mn}, \mathrm{Cr})_{3} \mathrm{O}_{4}$ oxide. Especially the first few 
$\mu \mathrm{m}$ in contact with the fuel gas seems to be enriched in Mn (Fig. 6c). The formation of this layer can be explained by the migration of transition metals from the steel through the Ag matrix to the interface, were the oxides are formed. The solubility and diffusivity of $\mathrm{Cr}$ in the bulk of $\mathrm{Ag}$ increase with increasing temperature, reaching values of $20 \mathrm{ppm}$ and $1.2 \cdot 10^{-9} \mathrm{~cm}^{2} \mathrm{~s}^{-1}$ respectively at $850^{\circ} \mathrm{C}$ [50]. A similar solubility of ca. $20 \mathrm{ppm}$ is found for Fe [50,51]. Although data are not available for $\mathrm{Mn}$ to the best of our knowledge, it is reasonable to expect that the solubility of $\mathrm{Mn}$ will also be of the same order of magnitude. It is worth noting here that the solubility of $\mathrm{Cr}$ and $\mathrm{Fe}$ in $\mathrm{Ag}$ is known to decrease drastically at elevated $\mathrm{pO}_{2}[50,51]$. Assuming diffusion of $\mathrm{Cr}$ through the braze to be the limiting factor for the growth of the oxide scale on top of the braze, an oxide scale thickness of about $0.3 \mu \mathrm{m}$ would be expected to form after $1000 \mathrm{~h}$ at $850^{\circ} \mathrm{C}$. The developed oxide scale is one order of magnitude larger, which is not surprising considering the polycrystalline nature of the braze and the anticipated increased diffusivity of $\mathrm{Cr}$ and $\mathrm{Mn}$ along grain boundaries [52]. Formation of oxide scale is also observed to take place to a similar extent inside the braze. This is believed to be caused by the large solubility and diffusivity of oxygen in the bulk of $A g$, with values of $200 \mathrm{ppm}$ and $1.7 \cdot 10^{-5} \mathrm{~cm}^{2} \mathrm{~s}^{-1}$ respectively at $850^{\circ} \mathrm{C}[53]$.

On a long term such on oxide layer could be beneficial, since the encapsulated Ag cannot evaporate. Also the diffusion of hydrogen, which could react with the oxygen in the bulk of the braze and form gaseous $\mathrm{H}_{2} \mathrm{O}$ bubbles, could be hindered, which will increase the long-term stability of the seal. 
While an oxide scale is found on top of the Ag-braze, none is found directly on the Crofer steel. Instead a thin Ag layer is directly in contact with Crofer steel, as observable in the elemental maps of $\mathrm{Ag}$ and Fe in Figure $6 \mathrm{~b}$ and in the overview image of this area (inlet Fig. 6a). Another interesting feature is the formation of a $\mathrm{Nb}$ rich Laves phase between this $\mathrm{Ag}$ layer and the $(\mathrm{Mn}, \mathrm{Cr})_{3} \mathrm{O}_{4}$ oxide in the braze, which is clearly visible as magenta line in EDS map in Figure 6d.

\subsubsection{Rim of the seal exposed to air}

As shown in Figure 7, the edges of some Crofer steel parts exposed to the air are heavily corroded ("breakaway corrosion"). The formed Cr-Fe-oxides seem to grow along the interface steel-braze and more $\mathrm{FeO}_{x}$ is formed over time, leading to a wedge like structure of the corroded area (Fig. 7a). In Figure 7c it can be seen how the formed $\mathrm{FeO}_{\mathrm{x}}$ "pushes" the $\mathrm{Ag}$ into the porous Ni-YSZ support of the cells, as indicated by the red arrows. Since the Ag is relatively soft at the operation temperature at $850{ }^{\circ} \mathrm{C}$, these findings are explainable. A corrosion, but to a lesser extent, of the spacer is also know from experiments in which a glass ceramic was used as sealant material. As shown in Figure $7 \mathrm{~b}$, the corrosion mainly occurs on the edges of the uncoated Crofer spacer, while the LSM coated interconnect seems to be less corroded after testing. This kind of break-away corrosion for uncoated Crofer steels have been reported in literature for temperatures as low as $600{ }^{\circ} \mathrm{C}[22,54]$. Therefore it is suggested, that a preoxidation of the Crofer steel or a protective coating could prevent/slow down the breakaway corrosion of these steel parts.

\subsubsection{TOF SIMS analysis}


As discussed in section 3.6.4, the evaporation of $\mathrm{Ag}$ during operation at higher temperatures could be problematic and should be investigated in more detail to predict the long-term stability of the sealant. While a deposition of highly conducting Ag in the Ni-YSZ electrode would be rather unproblematic, a slow evaporation of $\mathrm{Ag}$ from the sealant would decrease the gas tightness over time and eventually lead to failure of the SOC stack. Here, TOF-SIMS was used to investigate if $\mathrm{Ag}$ traces can be found in other parts of the cell after long-term testing. The cell was analyzed in two different locations, detailed images and spectra can be found in the supplementary material. The first spot is in the electrochemical active part of the cell, the second spot (spot 2, Fig. 12a) is directly under the $\mathrm{Ag}-\mathrm{Al}_{2} \mathrm{TiO}_{5}$ braze in the sealant area. No indication of $\mathrm{Ag}$ evaporation or re-deposition were found. Also in the active part of the cell, no enrichment of $\mathrm{Ag}$ was detected. Considering the high elemental sensitivity of the TOF-SIMS analysis (ppb range), Ag evaporation under the here used operation conditions only occurs to very little extend and a negative influence on the long-term stability can be excluded.

\section{Summary and Discussion}

The use of the $\mathrm{Ag}^{-} \mathrm{Al}_{2} \mathrm{TiO}_{5}$ composite braze as sealant for SOFC and SOEC application is feasible, but has some limitations. After the sealing process at $\sim 940{ }^{\circ} \mathrm{C}$ a gas tight joint was obtained between all tested joining partners; Crofer steel, coated with LSM or uncoated, can be joined to dense YSZ electrolytes and porous Ni-YSZ supports using this composite braze. The microstructural changes occurring over time at different places in the sealing are illustrated in Figure 8. In the center of the seal, not directly exposed to $\mathrm{O}_{2}$ or $\mathrm{H}_{2}$ containing atmospheres, no severe changes in the microstructure were observed after $900 \mathrm{~h}$ of operation (Fig. 8a). 
When exposed to reducing atmosphere, the $(\mathrm{Mn}, \mathrm{Cr})_{3} \mathrm{O}_{4}$ oxide scale, which was formed on the Crofer steel during the brazing process, starts to dissolve and $\mathrm{Mn}$ and $\mathrm{Cr}$ migrates from the steel through the Ag matrix towards a) the rim of the seal and b) the Ni-YSZ support (Fig. 8b). The remaining $(\mathrm{Mn}, \mathrm{Cr})_{3} \mathrm{O}_{4}$ oxide scale on the Crofer is not continuous anymore and $\mathrm{Ag}$ enclosures in the steel are found in the parts where the oxide scale is missing (Fig. 8b). At the rim of the seal exposed to $\mathrm{H}_{2}$, a dense layer of $(\mathrm{Mn}, \mathrm{Cr})_{3} \mathrm{O}_{4}$ oxide is found, the outer most layer of this oxide scale is enriched with $\mathrm{Mn}$. This oxide scale could be beneficial for the long-time stability, because it can prevent $\mathrm{H}_{2}$ from diffusing into the $\mathrm{Ag}$, where it could react with $\mathrm{O}_{2}$ and form steam bubbles. The effect on the long-term stability of the $\mathrm{Cr} / \mathrm{Mn}$ migration to the Ni-YSZ support is difficult to predict, but the effect is only observed in the first $500 \mu \mathrm{m}$ of the seal. Also the voids in the Crofer steel, properly caused by the diffusion of $\mathrm{Cr}$ and $\mathrm{Mn}$ (and to a very little extent Fe), are filled with Ag. Assuming that this process is dynamic and that at no point gaps/leaks occur at the interfaces, these phenomena are considered rather unproblematic for the long term stability.

When exposed to pure $\mathrm{O}_{2}$, several degradation phenomena related to the $\mathrm{Ag}^{-} \mathrm{Al}_{2} \mathrm{TiO}_{5}$ braze were found; 1) Delamination of the oxide scale from the steel, 2) formation of $\mathrm{Ag}_{2} \mathrm{CrO}_{4}$, and 3) evaporation of Ag. The first one reflects that the interface between the steel and the oxide scale is weak, and is only indirectly related to the Ag braze, which is still well attached to the oxide scale. But the possible diffusion (compared to a glass covered interconnect) of $\mathrm{O}_{2}$ through the braze could lead to an accelerated growth of the oxide scale and therewith to accelerated spalling of the same. The evaporation of $\mathrm{Ag}$ on the other hand could be critical for the long term stability of a seal. Assuming a continuous evaporation rate, a failure can be expected before the 
end of the planned life time for SOC operation $\left(>40000 \mathrm{~h}\right.$ ). Therefore the use in pure $\mathrm{O}_{2}$ (e.g. for sealing the oxygen electrode in SOEC operation mode) of the $\mathrm{Ag}-\mathrm{Al}_{2} \mathrm{TiO}_{5}$ braze is not recommend. The use in air on the other hand seems to be less critical. Even if some steel parts exposed to air corroded in the in dual atmosphere test (Fig. $8 \mathrm{c}$ ), the main part of the steel seems intact. Here, the coating or a pre-oxidation of the steel to form a protective oxide scale will be beneficial, as shown by Sofie et al. [42], where oxide scale growth and silver chromate formation were significantly reduced when the Crofer $22 \mathrm{APU}$ steel was coated with $\left(\mathrm{Co}, \mathrm{Mn}_{3} \mathrm{O}_{4}\right.$ (Co:Mn = 1:1). Also other measures should be taken to avoid gas mixing through the exposed sides of the anode support, which accelerates degradation at the outside of the spacer frame.

A porosity caused by formation of gaseous $\mathrm{H}_{2} \mathrm{O}$ bubbles in the Ag like reported by Singh et al. [49] was not observed, and the use of $\mathrm{Ag}-\mathrm{Al}_{2} \mathrm{TiO}_{5}$ as sealant in dual atmosphere is considered feasible.

\section{Conclusion}

Crofer was successfully joined to dense $\mathrm{YSZ}$ and porous $\mathrm{NiO}-\mathrm{YSZ}$ using $\mathrm{Ag}$ and $\mathrm{Ag}-\mathrm{Al}_{2} \mathrm{TiO}_{5}$ composite as brazing material. The brazing process can be carried out in air, the recommended brazing temperature is between 930 and $940{ }^{\circ} \mathrm{C}$. The use of $\mathrm{Al}_{2} \mathrm{TiO}_{5}$ as ceramic filler in the $\mathrm{Ag}$ braze allows the tuning of the thermal expansion coefficient to a large degree. A chemical reaction between the ceramic filler and the Ag was not found. Also all investigated interfaces in the joined assemblies showed a good adhesion of the braze after the joining process, no critical chemical reactions between the joining partners were observed. Leak testing at different 


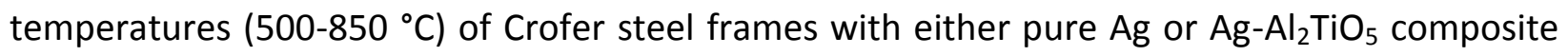
braze showed sufficient low leak rates for the use as sealant in SOFC/SOEC stacks.

Brazed Crofer/ $\mathrm{Ag}-\mathrm{Al}_{2} \mathrm{TiO}_{5} / \mathrm{Ni}-\mathrm{YSZ}$ and Crofer/ $\mathrm{Ag}-\mathrm{Al}_{2} \mathrm{TiO}_{5} / \mathrm{YSZ}$ assemblies were aged in reducing atmosphere and pure oxygen for $500 \mathrm{~h}$ at $850{ }^{\circ} \mathrm{C}$, respectively. No severe degradation was observed in reducing atmosphere. In pure oxygen delamination between the oxide scale and the steel occurred. Also $\mathrm{Ag}_{2} \mathrm{CrO}_{4}$ formation and evaporation of $\mathrm{Ag}$ was observed. Therefore use in pure oxygen is not recommended. A cell component test was performed to investigate the durability of the $\mathrm{Ag}-\mathrm{Al}_{2} \mathrm{TiO}_{5}$ seal when exposed to dual atmosphere. The test was successfully carried out for $900 \mathrm{~h}$ under electrolysis operation conditions $\left(-0.5 \mathrm{~A} \mathrm{~cm}^{2}, 850{ }^{\circ} \mathrm{C}\right)$, no cell degradation related to the $\mathrm{Ag}-\mathrm{Al}_{2} \mathrm{TiO}_{5}$ sealing was found. Changes in the microstructure, which are considered uncritical for the long-term stability, of the sealant at the rims exposed to fuel gas as well as to air were found. The formation of water bubbles or the evaporation of Ag were not observed, indicating that the developed $\mathrm{Ag}^{-} \mathrm{Al}_{2} \mathrm{TiO}_{5}$ braze system is applicable for the use in SOFC/SOEC stacks.

\section{Acknowledgement}

This work was supported financially by the Department of Energy Conversion and Storage, Technical University of Denmark and by the Energinet.dk through the projects ForskEL 2013-112013 "Solid Oxide Electrolysis for Grid Balancing" and the ForskEL project 10747 "Towards Smart Grid Ready SOFC". The authors also thank the technical staff at the Department of Energy Conversion and Storage for technical support in sample fabrication and characterization. 
7 References

[1] S.D. Ebbesen, M. Mogensen, J. Power Sources, 193 (2009) 349-358.

[2] P.Y. Yan, C.H. Cehng, A. Su, S.H. Chan, (2011) 4075-4078.

[3] J.E. O'Brien, C.M. Stoots, J.S. Herring, Nucl. Hydrogen Prod. Handb., (2011) 417-460.

[4] J.C. Ruiz-Morales, D. Marrero-Lopez, J. Canales-Vazquez, J.T.S. Irvine, RSC Adv., 1 (2011) 1403-1414.

[5] B. Yu, W. Zhang, J. Xu, J. Chen, Int. J. Hydrogen Energy, 35 (2010) 2829-2835.

[6] M. Ni, M.K.H. Leung, D.Y.C. Leung, Int. J. Hydrogen Energy, 33 (2008) 2337-2354.

[7] J. Hao, C. Deng, Q. Zan, J. Xu, Key Eng. Mater., 512-515 (2012) 1574-1578.

[8] H.T. Chang, C.K. Lin, C.K. Liu, J. Power Sources, 189 (2009) 1093-1099.

[9] A. Glauche, T. Betz, M. Ise, ECS Trans., 35 (2011) 157-165.

[10] J.W. Fergus, J.Power Sources, 147 (2005) 46-57.

[11] F. Smeacetto, M. Salvo, M. Ferraris, V. Casalegno, P. Asinari, A. Chrysanthou, J. Eur. Ceram. Soc., 28 (2008) 2521-2527.

[12] P.J. Howard, I. Szkoda, J.Fuel Cell Sci.Technol., 9 (2012) 041009.

[13] M. Kerstan, C. Rüssel, J. Power Sources, 196 (2011) 7578-7584. 
[14] H. Khedim, A. Connelly, H. Nonnet, D. Coillot, F. Mear, L. Montagne, Adv. Sci. Technol. (Stafa-Zuerich, Switz.), 64 (2010) 76-82.

[15] N. Caron, L. Bianchi, S. Méthout, J. Therm.Spray Technol., 17 (2008) 598-602.

[16] Y.S. Chou, J.W. Stevenson, P. Singh, J. Power Sources, 184 (2008) 238-244.

[17] K. Scott Weil, C.A. Coyle, J.T. Darsell, G.G. Xia, J.S. Hardy, J. Power Sources, 152 (2005) 97104.

[18] W. Liu, X. Sun, M.A. Khaleel, J. Power Sources, 185 (2008) 1193-1200.

[19] S. Ebbesen, C.R. Graves, A. Hauch, S.H. Jensen, M.B. Mogensen, J. Electrochem. Soc., 157 (2010) 1419-1429.

[20] R. Knibbe, M.L. Traulsen, A. Hauch, S.D. Ebbesen, M. Mogensen, J. Electrochem. Soc., 157 (2010) B1209.

[21] Y.S. Chou, J.W. Stevenson, L.A. Chick, J. Power Sources, 112 (2002) 130-136.

[22] M. Bram, L. Niewolak, N. Shah, D. Sebold, H.P. Buchkremer, J.Power Sources, 196 (2011) 5889-5896.

[23] R. Jordan, Am. Ceram. Soc. Bull., 87 (2008) 26-29.

[24] J.Y. Kim, J.S. Hardy, K.S. Weil, J.Electrochem.Soc., 152 (2005) J52.

[25] P.A. Lessing, J.Mater.Sci., 42 (2007) 3465-3476.

[26] J.T. Darsell, K.S. Weil, Int. J. Hydrogen Energy, 36 (2011) 4519-4524. 
[27] M. Galli, J. Janczak-Rusch, M. Szankowska, Advanced Engineering Materials, 11 (2009) 71-

74.

[28] J.S. Hardy, J.Y. Kim, E.C. Thomsen, K.S. Weil, J.Electrochem.Soc., 154 (2007) P32-P39.

[29] J.Y. Kim, J.S. Hardy, K. Scott Weil, J Am Ceram Soc, 88 (2005) 2521-2527.

[30] J.Y. Kim, J.S. Hardy, K.S. Weil, Int. J. Hydrogen Energy, 32 (2007) 3754-3762.

[31] J.Y. Kim, J.S. Hardy, S. Weil, Int J Hydrogen Energy, 32 (2007) 3655-3663.

[32] J.Y.Y. Kim, J.S. Hardy, K.S. Weil, J. Mater. Res., 20 (2005) 636-643.

[33] W. Kobsiriphat, S. Barnett, J. Fuel Cell Sci. Technol., 5 (2008) 011002.

[34] B. Kuhn, F.J. Wetzel, J. Malzbender, R.W. Steinbrech, L. Singheiser, J. Power Sources, 193 (2009) 199-202.

[35] B. Kuhn, E. Wessel, J. Malzbender, R.W. Steinbrech, L. Singheiser, Int. J. Hydrogen Energy, 35 (2010) 9158-9165.

[36] S. Le, Z. Shen, X. Zhu, X.L. Zhou, Y. Yan, K. Sun, N. Zhang, Y.X. Yuan, Y. Mao, J. Alloys Compd., 496 (2010) 96-99.

[37] M. Singh, T.P. Shpargel, R. Asthana, J. Mater. Sci., 43 (2008) 23-32.

[38] M.C. Tucker, C.P. Jacobson, L.C. De Jonghe, S.J. Visco, J. Power Sources, 160 (2006) 10491057.

[39] S. Dabbarh, E. Pfaff, A. Ziombra, A. Bezold, DVS-Ber., 263 (2010) 338-343. 
[40] S. Dabbarh, E. Pfaff, A. Ziombra, A. Bezold, Ceram. Trans., 215 (2010) 213-223.

[41] X. Zhou, K. Sun, Y. Yan, S. Le, N. Zhang, W. Sun, P. Wang, J. Power Sources, 192 (2009) 408413.

[42] S.W. Sofie, P. Gannon, V. Gorokhovsky, J. Power Sources, 191 (2009) 465-472.

[43] H.W. Abernathy, E. Koep, C. Compson, Z. Cheng, M. Liu, J. Phys. Chem. C, 112 (2008) 13299-13303.

[44] W. Kiebach, M. Chen, R. Knibbe, L. Mikkelsen, K.B. Frederiksen, P.V. Hendriksen, Proc. ASME Int. Conf. Fuel Cell Sci., Eng., Technol., 8th, 2 (2010) 655-665.

[45] M. Nagano, S. Nagashima, H. Maeda, A. Kato, Ceram. Int., 25 (1999) 681-687.

[46] R. Uribe, C. Baudin, L. Mazerolles, D. Michel, J. Mater. Sci., 36 (2001) 5105-5113.

[47] P.H. Larsen, C. Bagger, S. Linderoth, M. Mogensen, S. Primdahl, M.J. Jørgensen, P.V., Hendriksen, B. Kindl, N. Bonanos, F.W. Poulsen, K.A. Maegaard, In: Solid Oxide Fuel Cells VII, H. Yokokawa, S.C. Singhal, Editors, The Electrochemical Society Proceedings Series, Pennington, NJ, 16 (2001) p. 28.

[48] Z.G. Lu, J.H. Zhu, Electrochem. Solid-State Lett. 10 (2007) B179.

[49] P. Singh, Z. Yang, V. Viswanathan, J.W. Stevenson, J. Mater. Eng. Perform. 13 (2004) 287294.

[50] G. Neumann, M. Pfundstein, P. Reimers, Phys. Stat. Sol. (a) 64 (1981) 225-232. 
[51] J. Bernardini, A. Combe-Brun, J. Cabane, Acad. Des Sciences 269 (1969) 287-289.

[52] R.W. Balluffi, R. F. Mehl Medalist, Metall. Trans. B 13B (1982) 527-553.

[53] J.-H. Park, Mater. Lett. 9 (1990) 313-316.

[54] Å.H. Perrson, L. Mikkelsen, P.V. Hendriksen, M.A.J. Somers, J. Alloy Compd. 521 (2012)

$16-29$. 
Table 1: EDS composition (at. \%) for $\mathrm{Ag}_{-} \mathrm{Al}_{2} \mathrm{TiO}_{5}$ brazed assemblies. Important values marked bold.

\begin{tabular}{|c|c|c|c|c|c|c|c|c|c|c|}
\hline \multicolumn{11}{|c|}{ EDS composition analysis (at. \%) for Crofer/ $\mathrm{Ag} / \mathrm{NiO}-\mathrm{YSZ}$ joint brazed at $930^{\circ} \mathrm{C}$} \\
\hline & $\mathrm{Fe}$ & $\mathrm{Cr}$ & $\mathrm{Mn}$ & $\mathrm{Ag}$ & Al & $\mathrm{Ti}$ & $\mathrm{Ni}$ & $\mathrm{Zr}$ & Y & $\mathrm{O}$ \\
\hline pt 1, Fig 3b & & & & 92.1 & & & & & & 7.9 \\
\hline pt 2, Fig 3b & & & & & 28.0 & 12.6 & & & & 59.5 \\
\hline pt 3, Fig 3b & 0.7 & 0.3 & & 9.7 & & & 27.1 & 20.9 & 1.5 & 40.0 \\
\hline pt 4, Fig 3b & & & & & & & 54.7 & & & 45.5 \\
\hline pt 5, Fig 3b & & & & 1.5 & & & 6.4 & 33.7 & 2.5 & 56.0 \\
\hline pt 1, Fig 3c & 76.9 & 20.9 & & & & & & & & 2.3 \\
\hline pt 2 , Fig $3 c$ & 79.9 & 20.9 & 0.2 & & & & & & & \\
\hline pt 3 , Fig 3c & 4.5 & 32.9 & 13.4 & 28.1 & & & & & & 28.1 \\
\hline pt 4, Fig 3c & & & & & 27.9 & 13.4 & & & & 58.7 \\
\hline pt 5, Fig 3c & & & & 94.0 & & & & & & 6.0 \\
\hline \multicolumn{11}{|c|}{ 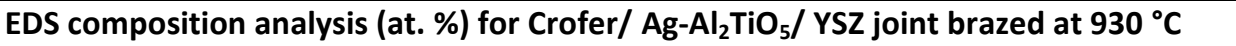 } \\
\hline & $\mathrm{Fe}$ & $\mathrm{Cr}$ & $\mathrm{Mn}$ & $\mathrm{Ag}$ & Al & $\mathrm{Ti}$ & $\mathrm{Ni}$ & $\mathrm{Zr}$ & Y & 0 \\
\hline pt 1, Fig 3g & 0.7 & 0.42 & & 89.22 & & & & & & 9.67 \\
\hline pt 2, Fig 3g & 1.3 & 0.9 & 0.3 & 63.6 & 14.7 & 6.0 & & & & 13.2 \\
\hline pt 3, Fig 3g & 0.3 & & & & 25.1 & 15.9 & & & & 58.9 \\
\hline pt 4, Fig 3g & 28.3 & 35.2 & 16.5 & 28.3 & & & & & & 17.4 \\
\hline pt 5, Fig 3g & 78.2 & 19.4 & & & & & & & & 2.4 \\
\hline pt 6, Fig 3g & 63.1 & 22.2 & & 7.5 & 1.7 & & & & & 5.6 \\
\hline pt 1, Fig 3h & & & & & & & 24.6 & 14.5 & 2.8 & 58.1 \\
\hline pt 2, Fig 3h & 0.4 & & & 18.3 & 1.3 & 0.1 & & 30.9 & 6.0 & 43.1 \\
\hline pt 3, Fig 3h & 0.7 & 0.9 & & 49.7 & 21.8 & 11.2 & & & & 15.7 \\
\hline pt 4, Fig 3h & & & & & 26.5 & 14.0 & & & & 59.5 \\
\hline pt 5, Fig 3h & 0.4 & 0.7 & & 16.1 & 32.9 & 17.3 & & & & 32.7 \\
\hline
\end{tabular}

Table 2: EDS composition (at. \%) for $\mathrm{Ag}-\mathrm{Al}_{2} \mathrm{TiO}_{5}$ brazed assemblies after ageing in different atmospheres. Important values marked in bold.

\begin{tabular}{|c|c|c|c|c|c|c|c|c|c|c|}
\hline \multicolumn{11}{|c|}{$\begin{array}{l}\text { EDS composition analysis (at. \%) for Crofer/ } \mathrm{Ag}_{-} \mathrm{Al}_{2} \mathrm{TiO}_{5} / \mathrm{NiO}-\mathrm{YSZ} \text { joint after } 500 \mathrm{~h} \text { in } 4.5 \% \mathrm{H}_{2} / 50 \% \mathrm{H}_{2} \mathrm{O} / 45.5 \% \mathrm{Ar} \text { at } \\
850^{\circ} \mathrm{C}\end{array}$} \\
\hline & $\mathrm{Fe}$ & $\mathrm{Cr}$ & $\mathrm{Mn}$ & $\mathrm{Ag}$ & $\mathrm{Al}$ & $\mathrm{Ti}$ & $\mathrm{Ni}$ & $\mathrm{Zr}$ & $Y$ & 0 \\
\hline pt 1 , Fig $4 a$ & 75.0 & 17.4 & 0 & 0.0 & 0 & 0.0 & 1.15 & 0.0 & 0 & 6.3 \\
\hline pt 2, Fig 4a & 75.8 & 17.5 & 0 & 0 & 0.1 & 0 & 1.1 & 0 & 0 & 5.4 \\
\hline pt 3, Fig 4a & 2.1 & 7.4 & 0.2 & 50.6 & 1.2 & 1.9 & 0.6 & 0 & 0 & 36.0 \\
\hline pt 4, Fig 4a & 2.8 & 1.9 & 0.6 & 76.7 & 0.7 & 0.5 & 0 & 0 & 0 & 16.8 \\
\hline pt 5, Fig 4a & 2.2 & 13.6 & 0 & 30.0 & 2.7 & 11.2 & 1.3 & 0 & 0 & 38.9 \\
\hline pt 6, Fig 4a & 0.4 & 0.4 & 0.2 & 0 & 19.5 & 17.5 & 0.4 & 0 & 0 & 61.4 \\
\hline pt 7, Fig 4a & 0.2 & 0.9 & 0.2 & 79.0 & 0.8 & 0.4 & 0 & 0.3 & 0 & 18.1 \\
\hline pt 8 , Fig $4 a$ & 3.1 & 28.0 & 5.4 & 0 & 1.3 & 1.5 & 0.2 & 0 & 0 & 60.4 \\
\hline pt 9, Fig 4a & 0.8 & 0.8 & 0.5 & 0.3 & 1.8 & 6.4 & 1.6 & 26.0 & 1.1 & 60.6 \\
\hline pt 10, Fig $4 a$ & 1.5 & 0.7 & 0 & 43.2 & 0.3 & 0.6 & 7.5 & 10.0 & 1.1 & 34.9 \\
\hline
\end{tabular}




\begin{tabular}{|c|c|c|c|c|c|c|c|c|c|}
\hline \multicolumn{10}{|c|}{ 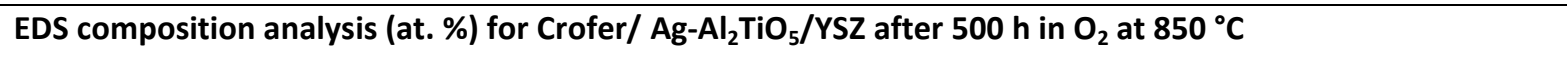 } \\
\hline & $\mathrm{Fe}$ & $\mathrm{Cr}$ & $\mathrm{Mn}$ & $\mathrm{Ag}$ & Al & $\mathrm{Ti}$ & $\mathrm{Zr}$ & Y & $\mathrm{O}$ \\
\hline pt 1, Fig 4b & 78.2 & 18.2 & 0.1 & 0.2 & 0.1 & 0.3 & 0.1 & 0 & 0.3 \\
\hline pt 2, Fig 4b & 2.2 & 42.3 & 0.1 & 2.7 & 0.5 & 0.5 & 0.1 & 0 & 51.7 \\
\hline pt 3, Fig 4b & 3.5 & 14.2 & 1.6 & 18.1 & 9.0 & 8.3 & 0.2 & 0 & 45.1 \\
\hline pt 4, Fig 4b & 2.6 & 4.9 & 0.5 & 7.0 & 19.9 & 11.6 & 0.1 & 0 & 53.4 \\
\hline pt 5, Fig 4b & 1.2 & 4.4 & 0.2 & 12.3 & 12.4 & 7.6 & 1.8 & 3.4 & 56.6 \\
\hline pt 6, Fig 4b & 0.5 & 0 & 0 & 0.3 & 0 & 0.6 & 37.6 & 4.4 & 56.5 \\
\hline pt 7, Fig 4b & 2.0 & 14.1 & 1.4 & 28.6 & 4.6 & 6.2 & 0 & 0 & 43.0 \\
\hline pt 8 , Fig 4b & 1.2 & 0.3 & 0.3 & 82.6 & 0.6 & 0.2 & 0 & 0 & 14.8 \\
\hline pt 9, Fig 4b & 2.2 & 16.4 & 1.5 & 31.1 & 5.0 & 6.5 & 0.1 & 0 & 37.1 \\
\hline
\end{tabular}




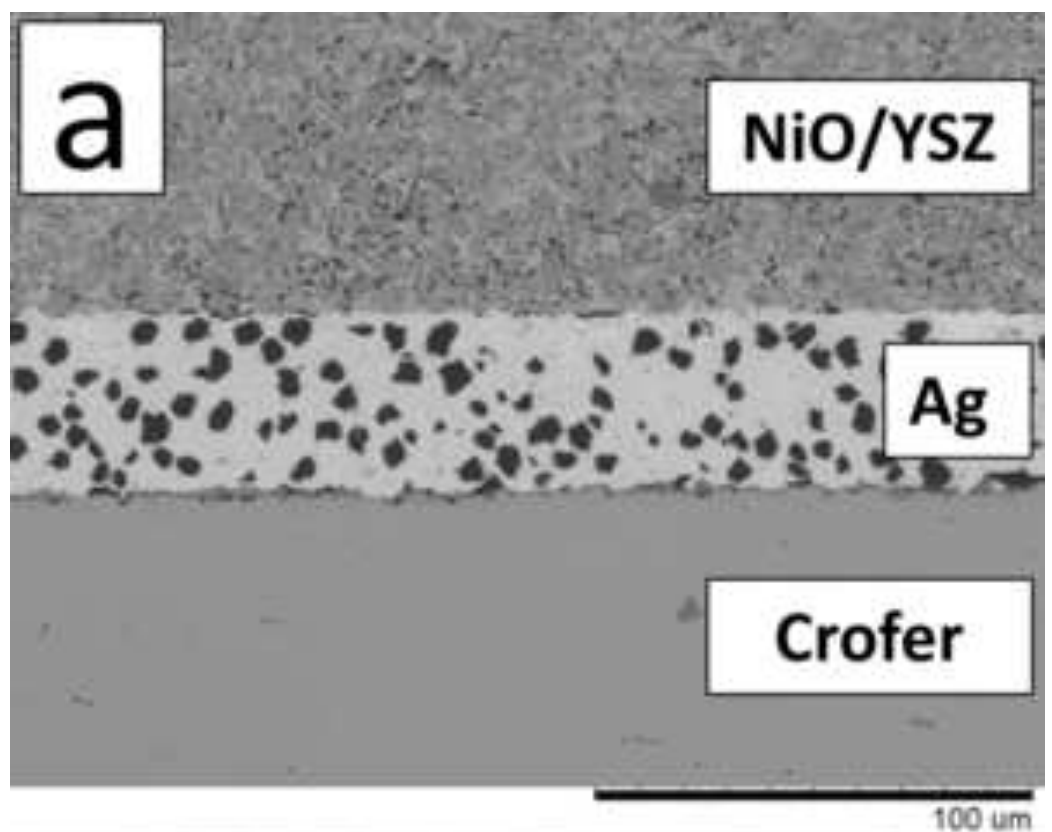

$100 \mathrm{um}$
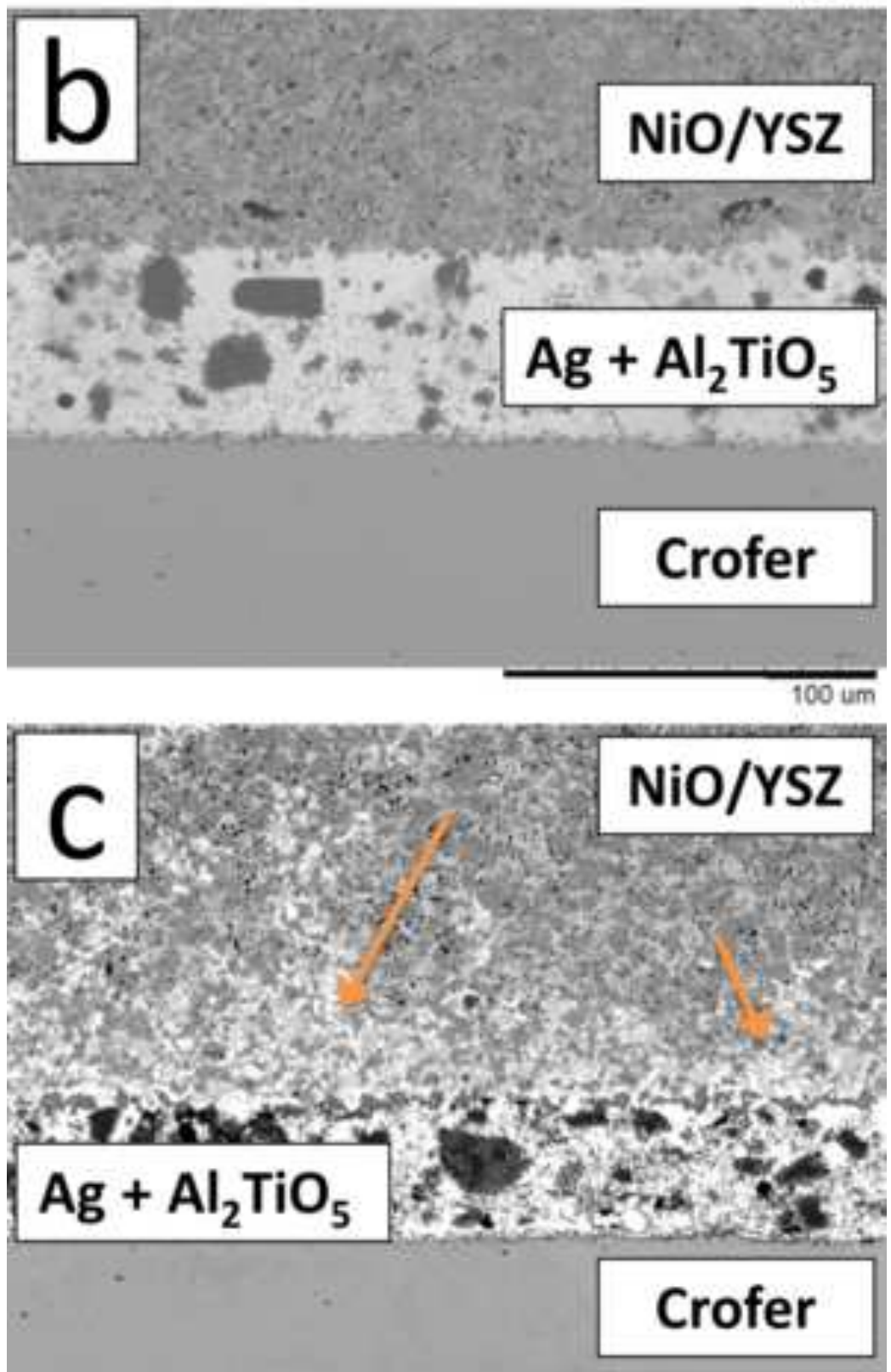

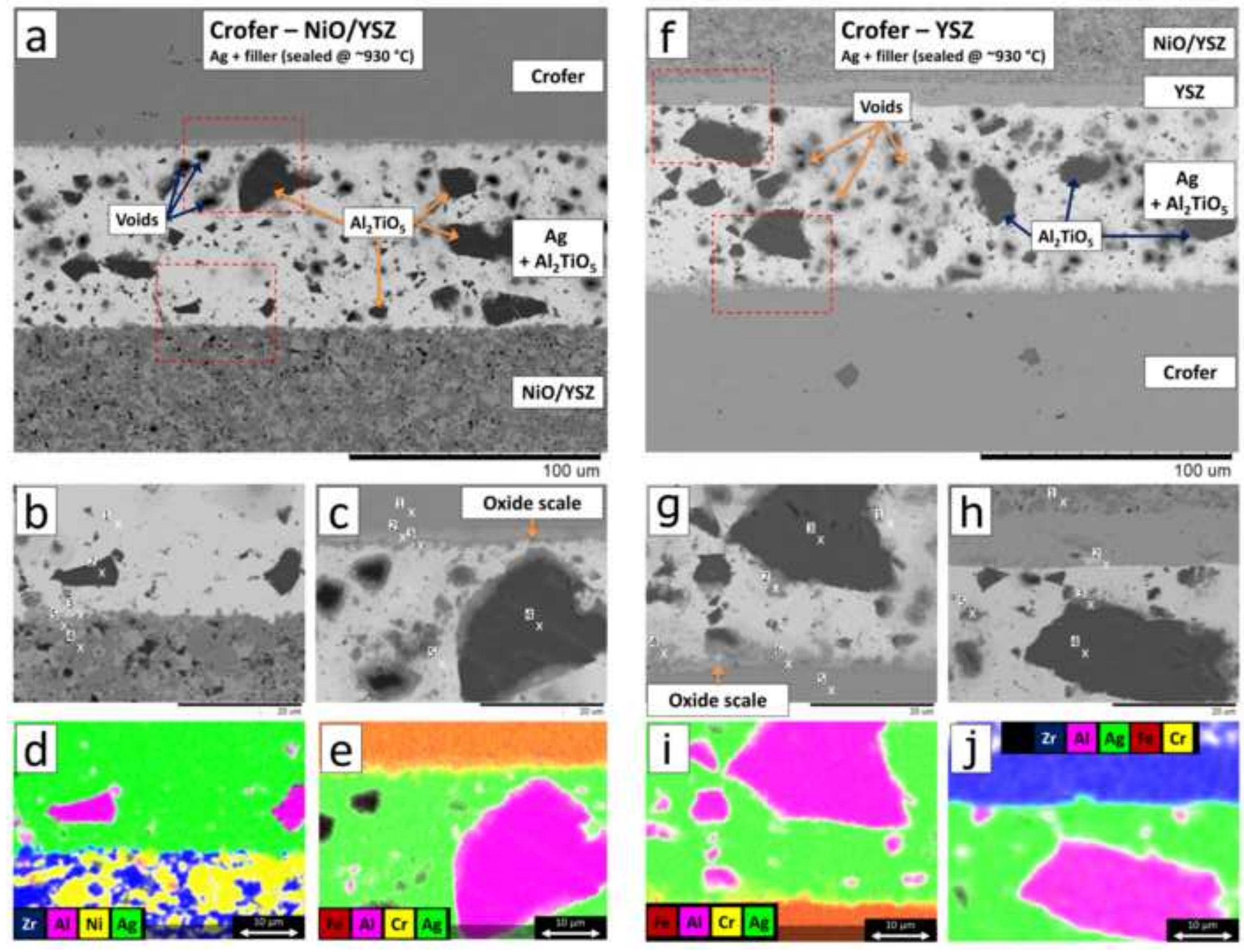

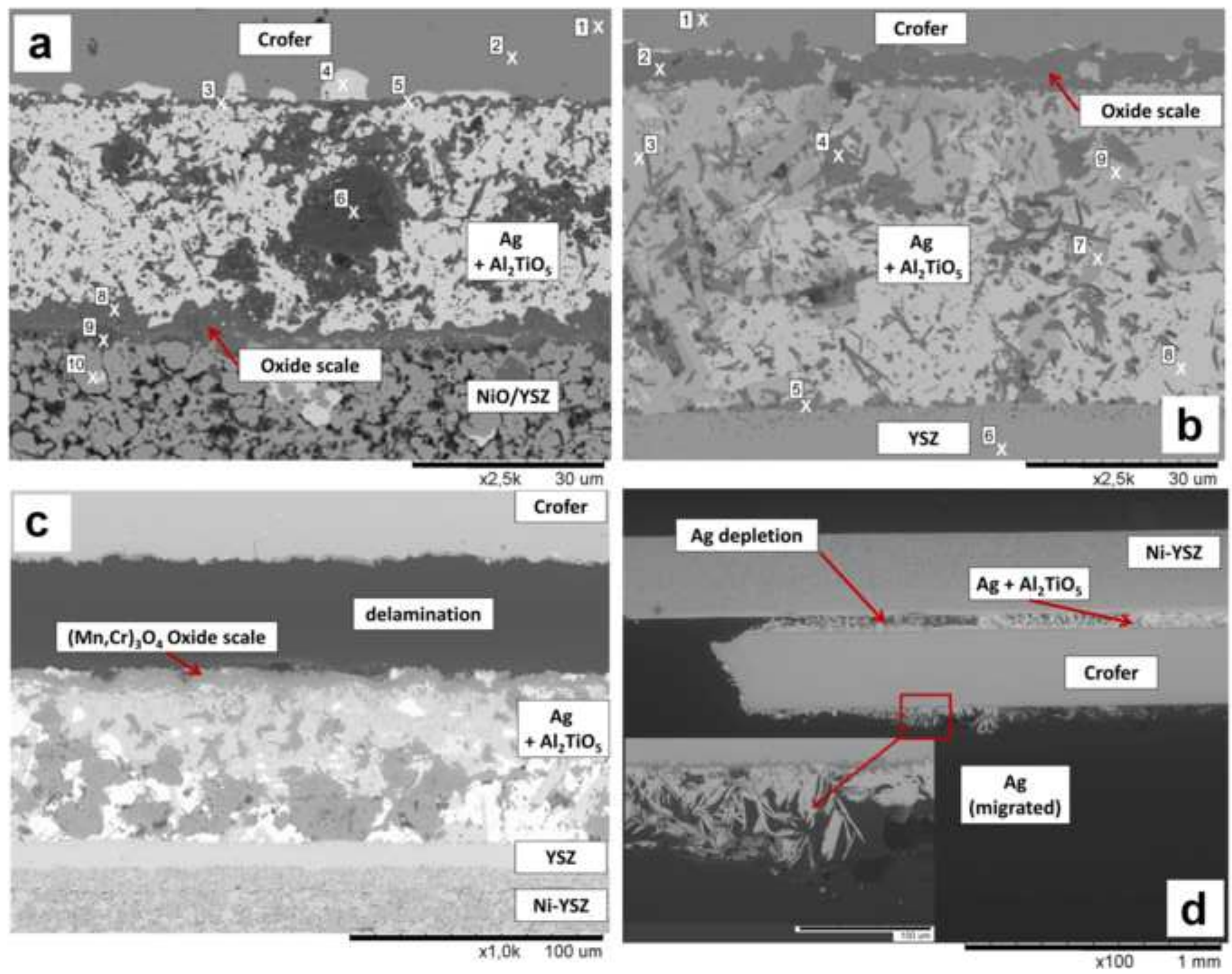


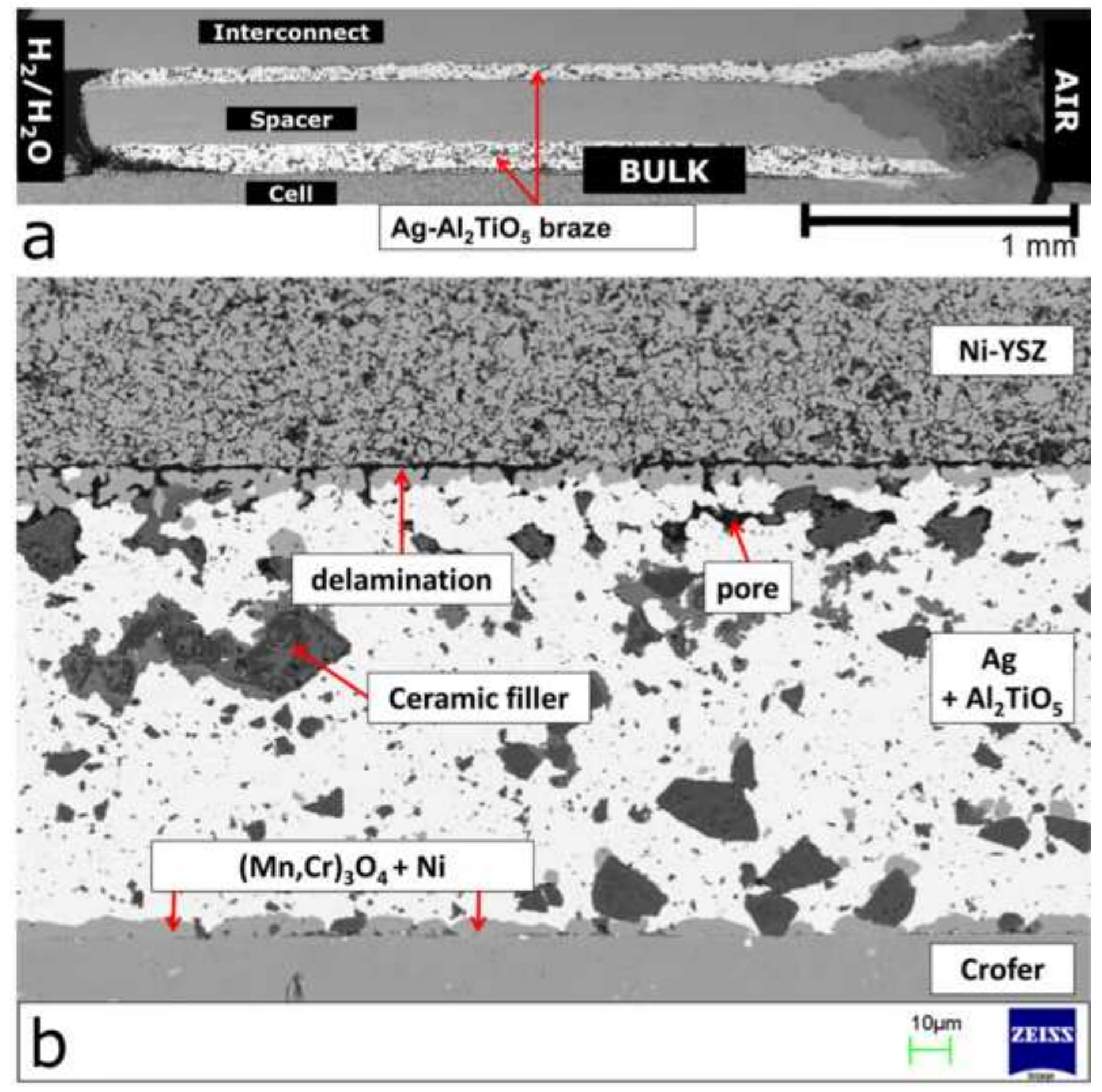

Figure 5

.

\section{$-1$}

4

Cell

(

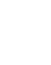




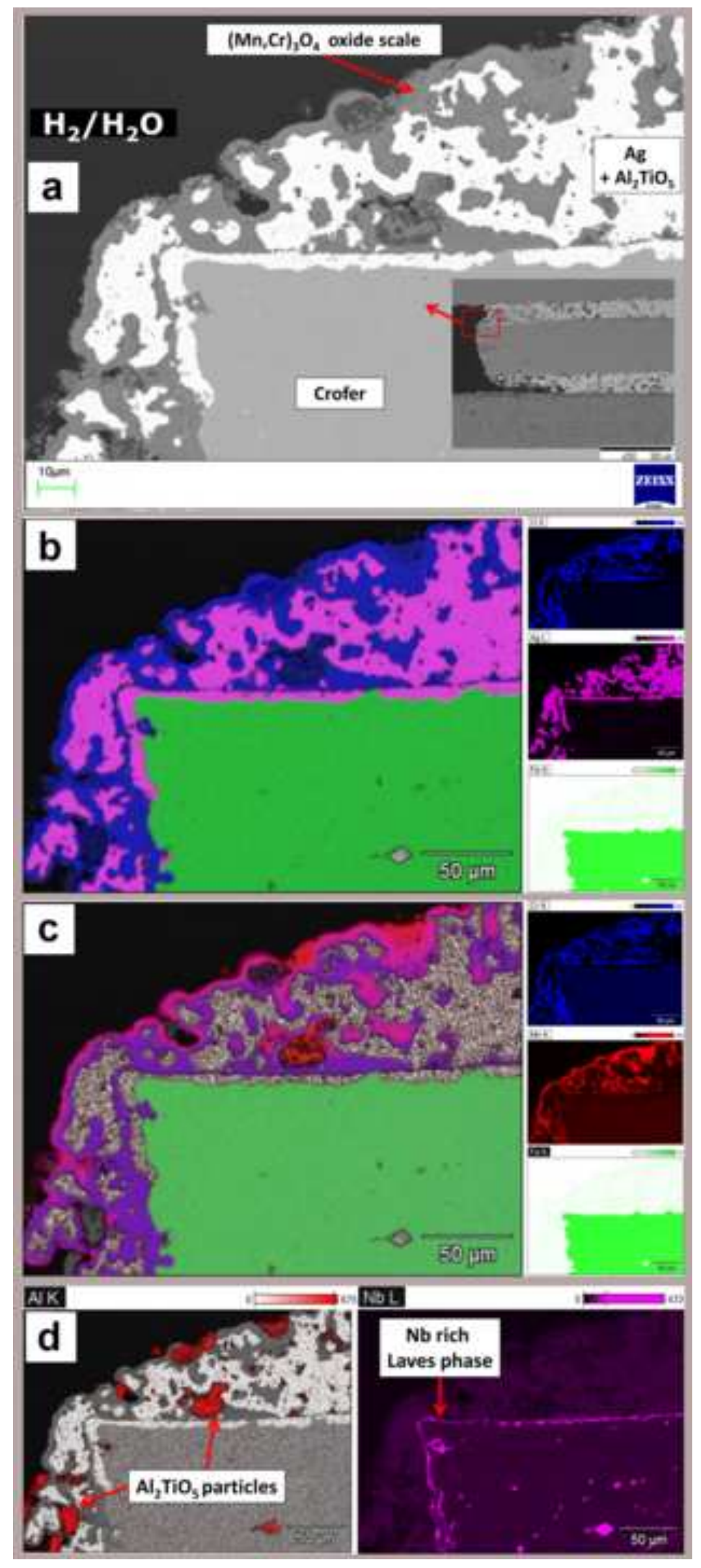

Figure 6 

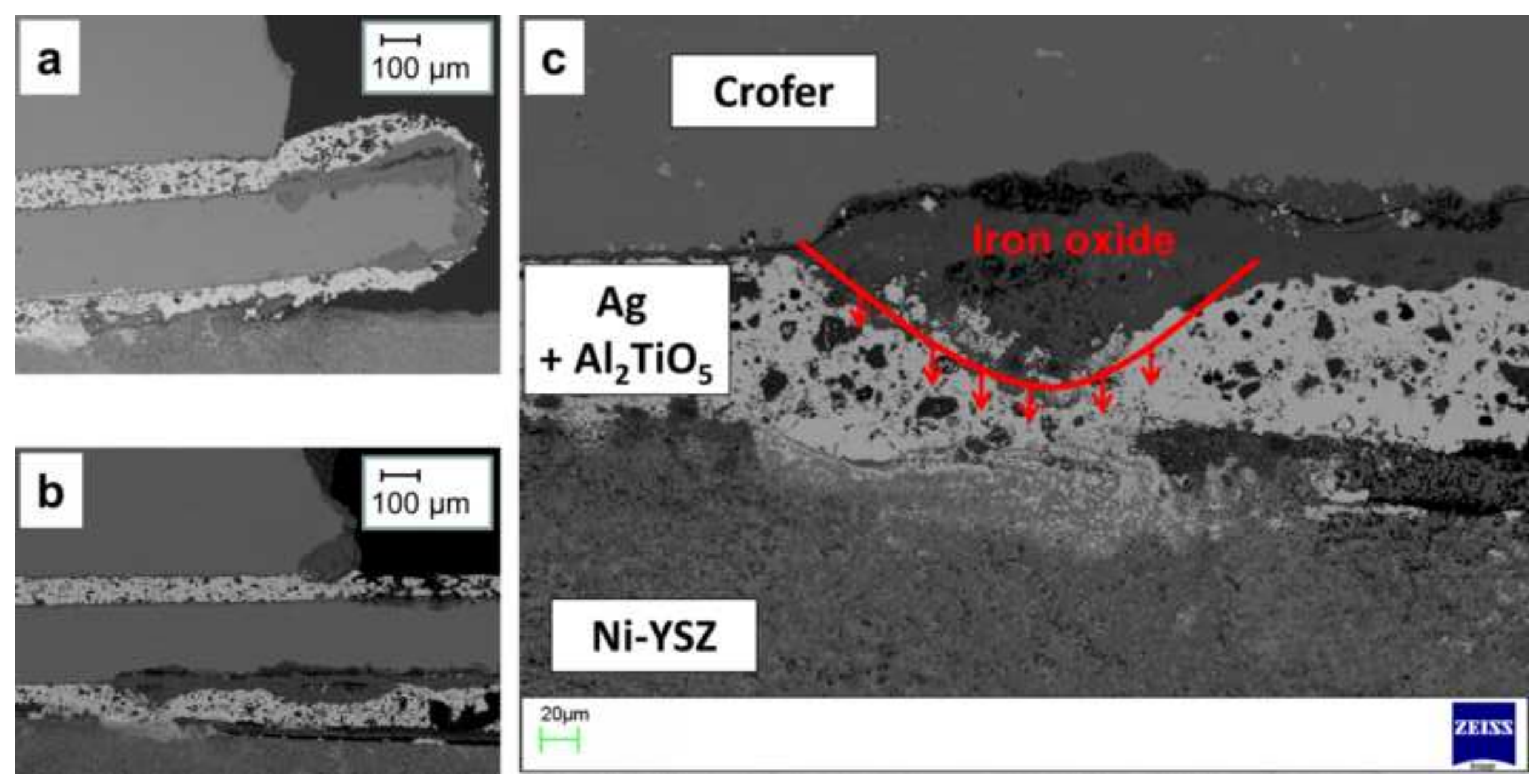

\section{Ni-YSZ}



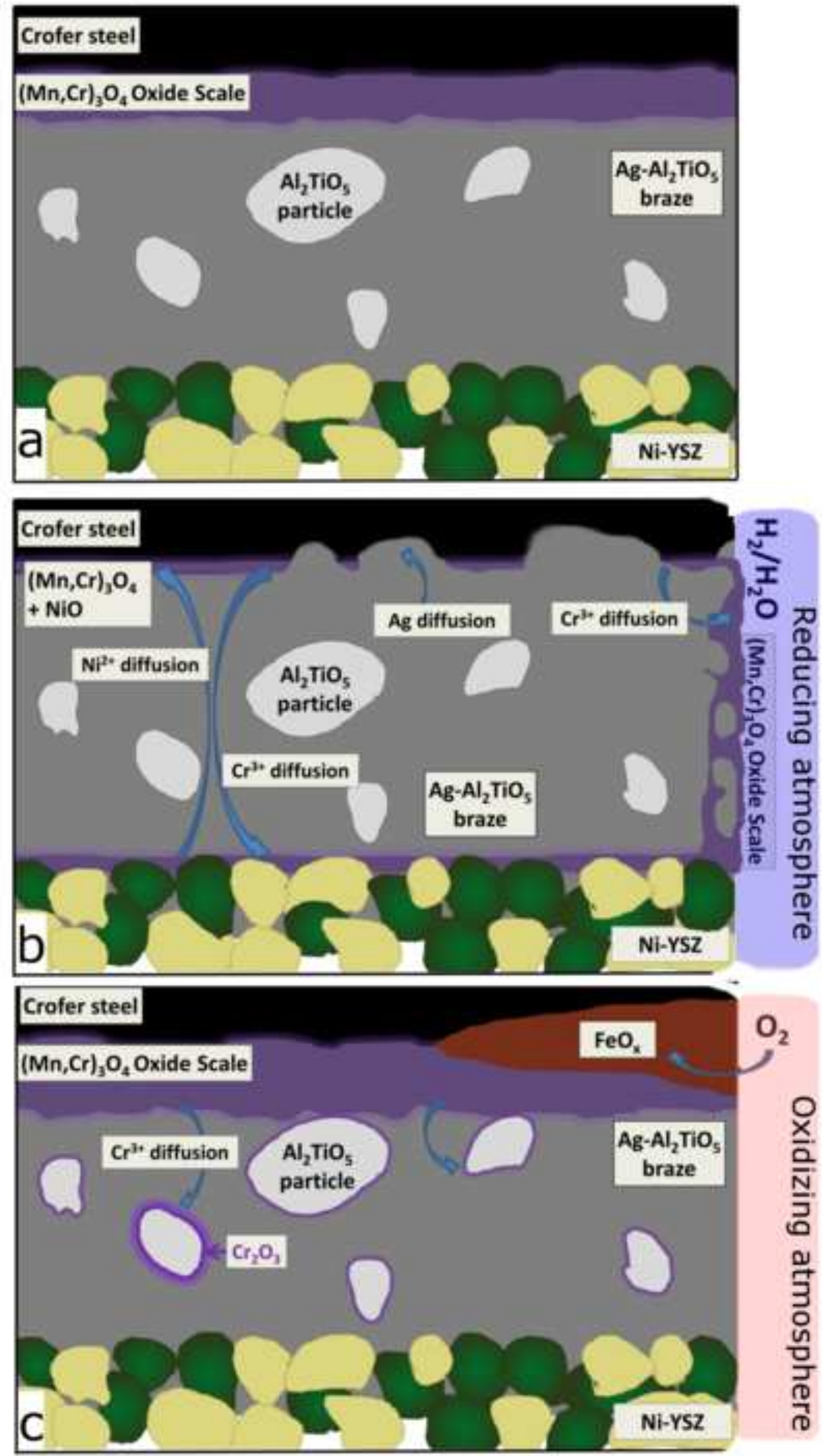
Figure captions:

Figure 1: a) Thermal expansion curves of pure $\mathrm{Ag}$ (black line), $\mathrm{Ag}$ with $5 \mathrm{wt} \% \mathrm{Al}_{2} \mathrm{TiO}_{5}$ (red line) and $\mathrm{Ag}$ with $15 \mathrm{wt}$ \% $\mathrm{Al}_{2} \mathrm{TiO}_{5}$ (blue line). b) Change of the thermal expansion coefficient (TEC) in dependence of the amount of ceramic filler. The TEC of Crofer 22 APU is added for comparison (grey dotted line).

Figure 2: SEM pictures of Crofer/Ag-braze/NiO-YSZ samples joint at different temperatures. a) pure Ag brazed @ $920^{\circ} \mathrm{C}$, b) Ag- $\mathrm{Al}_{2} \mathrm{TiO}_{5}$ brazed @ $935^{\circ} \mathrm{C}$ and c) $\mathrm{Ag}-\mathrm{Al}_{2} \mathrm{TiO}_{5}$ brazed @ $950{ }^{\circ} \mathrm{C}$. The orange arrows in $\mathrm{c}$ ) mark $\mathrm{Ag}$ diffusion into the porous NiO-YSZ support.

Figure 3: a) Overview SEM image of Crofer brazed to the NiO-YSZ support of a SOC half-cell using $\mathrm{Ag}-\mathrm{Al}_{2} \mathrm{TiO}_{5}$ as braze. The red dotted frames mark regions displaying the interface $\mathrm{Ag}-\mathrm{Al}_{2} \mathrm{TiO}_{5}$ braze - NiO-YSZ (b) the interface Ag- $\mathrm{Al}_{2} \mathrm{TiO}_{5}$ braze - Crofer (c) in higher magnification. The EDS maps of these two interfaces are shown in d) and e), respectively. f) Overview SEM image of Crofer brazed to the YSZ electrolyte of a SOC half-cell using $\mathrm{Ag}_{-}-\mathrm{Al}_{2} \mathrm{TiO}_{5}$ as braze. The red dotted frames mark regions displaying the interface $\mathrm{Ag}_{-} \mathrm{Al}_{2} \mathrm{TiO}_{5}$ braze - Crofer (g) and the interface $\mathrm{Ag}-\mathrm{Al}_{2} \mathrm{TiO}_{5}$ braze YSZ (h) in higher magnification. The EDS maps of these two interfaces are shown in i) and j), respectively.

Figure 4: a) SEM overview image of Crofer steel brazed to the Ni-YSZ support of a half cell after exposure to reducing atmosphere for $500 \mathrm{~h}, \mathrm{~b})$ SEM overview image of Crofer steel brazed to the YSZ electrolyte of a half cell after exposure to oxidizing atmosphere for $500 \mathrm{~h}, \mathrm{c}$ ) SEM overview image of delaminated sample of Crofer steel brazed to the YSZ electrolyte of a half cell after exposure to oxidizing atmosphere for $500 \mathrm{~h}$, d) SEM overview image of sample edge of Crofer steel brazed to the YSZ electrolyte of a half cell after exposure to oxidizing atmosphere for $500 \mathrm{~h}$ showing evaporation/redistribution of $\mathrm{Ag}$.

Figure 5: a) Representative low magnification SEM image of the sealing area of the cell component test, b) SEM image of center part of the sealing part of the cell component test. 
Figure 6: a) SEM image of rim of the sealing exposed to the fuel side, b-d) SEM images and EDS mapping of rim of the sealing exposed due the fuel side p. b) EDS maps of O, Fe and Ag; c) EDS maps of $\mathrm{Cr}, \mathrm{Mn}$ and $\mathrm{Fe}$; d) EDS maps of $\mathrm{Al}$ and $\mathrm{Nb}$.

Figure 7: SEM image of rim of the sealing exposed to Air of the part of the cell component test. a) SEM image of area with average corrosion; b) SEM image of sealing area with large amount of corrosion; c) SEM image with higher magnification of sealing area with corrosion.

Figure 8: Illustration of a) center part of the sealing area after brazing, b) sealing area exposed to reducing atmosphere and $\mathrm{c}$ ) sealing area exposed to oxidizing atmosphere. 
